\title{
GÊNESE DA BAUXITA DE LAGES - SC
}

\section{S.M. B. Oliveira*}

\section{RESUMO}

Este trabalho trata dos produtos de alteração intempérica das rochas alcalinas do distrito de Lages, estado de Santa Catarina, que constituem a mais meridional ocorrência de bauxita conhecida no continente sul-americano. A alteração destas rochas sob condições adequadas de temperatura e disponibilidade de água levou à formaçấo de um depósito de bauxita de $5 \cdot 10^{6}$ tons com $\mathrm{Al}_{2} \mathrm{O}_{3}>50 \%$.

As características mineralógicas e químicas dos diferentes horizontes do perfil de alteração, da rocha fresca até os niveis superiores, são descritas. Ocorre uma transformação da assembléia mineral primária (K-feldspato, nefelina e egirina) em uma assembléia secundária composta de gibbsita e goethita ou de halloisita/caolinita e goethita. É um processo de laterização que envolve lixiviação da sillica e álcalis e concentração de alumina, como é demonstrado pelos cálculos isovolumétricos.

A análise destes dados sugere que a textura e estrutura da rocha, juntamente com a posição topográfica do perfil são os principais fatores que controlam o processo de bauxitizaçāo.

O depósito de Lages é comparado com outros depósitos similares desenvolvidos sobre rochas alcalinas como Poços de Caldas e Arkansas.

\section{ABSTRACT}

This paper deals with the products of wathering of alkaline rocks of the Lages district, state of Santa Catarina, the southernmost known occurence of bauxite in South America. The alteration of these rocks under suitable conditions of temperature and availability of water has led to the formation of a bauxite deposit of $5 \cdot 10^{6}$ tons of $\mathrm{Al}_{2} \mathrm{O}_{3}>50 \%$.

The chemical and mineralogical characteristics of the different horizons of the alteration profile from the fresh rock to the uppermost levels are here described. There is a transformation of the primary mineral assemblage of K-feldspar, nepheline and aegirine to a secondary one of gibbsite and goethite or halloysite/kaolinite and goethite. It is a lateratisation process involving leaching of silica and alkalies and concentration of alumina, as demonstrated by isovolumetric calculations.

The analysis of these data suggests that texture and structure of the rock and topographic site are the principal factors controlling the process of bauxitisation.

The bauxite deposit of Lages is compared with other similar deposits developed upon alkaline rocks like Poços de Caldas and Arkansas.

\section{INTRODUCุÃO}

Ao norte da cidade de Lages, no estado de Santa Catarina, ocorrem rochas alcalinas no contexto de uma estrutura dômica conhecida como "Domo de Lages". Essas rochas foram assinaladas pela primeira vez na literatura em 1933, quando Otávio Barbosa descreveu amostras coletadas por Glycon de Paiva (BARBOSA, 1933). A partir daf alguns artigos foram publicados, dando conta do mapeamento geológico, da descrição das unidades litológicas presentes, da caracterização da estrutura regional e de dados geocronológicos. Entre estes, os mais importantes sāo os de LOCZY (1968), JOST (1967), AMARAL et al. (1967) e GUAZELLI \& FEIJÓ (1970). Na década de setenta, apareceram na literatura geológica trabalhos sobre os produtos de alteração supérgena das rochas alcalinas: LEPREVOST (1971) publicou dados sobre a composição química e mineralógica das bauxitas, LINDSTAED (1972) estudou o processo de alteraçāo intempérica e, finalmente, SZUBERT \& VERGARA (1975) avaliaram as reservas de minério. Estudos mais pormenorizados sobre os carbonatitos associados às rochas alcalinas sao devidos a SCHEIBE (1979) e SCHEIBE \& FORMOSO (1982). Recentemente foi publicada uma caracterização petrográfica mais detalhada das rochas alcalinas por SCHEI$\mathrm{BE}$ et al. (1984).

$O$ objetivo do presente trabalho é o de caracterizar, no plano mineralógico e geoquimico, os diferentes horizontes que compōem os perfis de alteração sobre as rochas alcalinas e de

\footnotetext{
- Depto. Geol. Geral, IG-USP

Bolsista da FAPESP
} 
determinar os fatores que regern o fenômeno de sua evolução supérgena. $\mathbf{A}$ análise destes dados culmina com uma hipótese sobre a história evolutiva da jazida, contribuindo assim para o domínio das investigaçōes no campo da metalogênese supérgena.

\section{O MEIO FISICO}

$O$ estudo dos diferentes aspectos do meio fisico informa sobre as condiçōes nas quais se dá o processo de alteraçāo intempérica.

\section{Geologia}

\section{Traços regionais}

A instrusáo do magma alcalino provocou - soerguimento dos estratos sedimentares da bacia do Paraná, de modo que toda a sequêencia gondwânica aflora na regiāo de Lages.

$\mathrm{O}$ domo, de forma grosseiramente circular com cerca de $1000 \mathrm{~km}^{2}$ de superfície, situa-se a oeste da escarpa do Primeiro Planal to da Serra Geral (Grupo Estrada Nova), sendo circundado a norte, a leste e a sul pela escarpa do Segundo Planalto da Serra Geral (Formaçס̄es Botucatu e Serra Geral). Em disposição concéntrica e mergulhos centrifugos, afloram no domo, da borda para o centro, os sedimentos da Formaçăo Rio do Rastro, Grupo Passa Dois, Grupo Guatá e Grupo Itararé (Fig. 1). O contato entre as camadas sedimentares dos Grupos Guatá e Passa Dois parece ser o nível preferido pelos corpos alcalinos, de modo que estes se dispõem aproximadamente em um círculo com cerca de $25 \mathrm{~km}$ de diâmetro (SCHEIBE et al., 1984), como se vế na Figura 1. Os principais corpos alcalinos são mais ou menos equidimensionais com poucos quilōmetros de diâmetro; suas áreas de afloramento perfazem um total de $50 \mathrm{~km}^{2}$.

Nos contatos entre os sedimentos e as rochas alcalinas não foi observado metamorfismo de contato, embora sejam visiveis auréolas de cozimento, o que, na opinião de LOCZY (1968), prova o caráter hipoabissal da intrusão.

As estruturas mais conspícuas consistem num sistema anelar de falhamento de até $350 \mathrm{~m}$ de rejeito. O levantamento dômico teria precedido a deposiçăo do arenito Botucatu, mas a fase principal da atividade vulcânica seria pósBotucatu (LOCZY, 1968). Dados geocronológicos relativos a uma das intrusoes indicam idade de 65 milhōes de anos (AMARAL et al., 1967).

\section{As rochas alcalinas}

SCHEIBE et al. (1984) distinguem quatro grandes grupos de rochas alcalinas no distrito de Lages:
- rochas alcalinas leucocráticas;

- rochas ultrabásico-al calinas;

- carbonatitos e rochas associadas;

- brechas vulcânicas.

Este trabalho trata apenas da alteração das rochas alcalinas leucocráticas, que săo, de longe, as dominantes. Estas, segundo os autores citados, sđo principalmente os fonólitos do Morro do Tributo, Serra do Cadeado e Serra da Chapada, e os fonólitos porfiríticos da Serra da Farinha Seca e de outros pequenos corpos. Um corpo de nefelinasienito porfirítico aflora a leste (Cerro Alto) e três pequenos corpos de analcita-traquito são encontrados entre os fonólitos da Serra da Chapada e da Serra do Cadeado (Fig. 1).

Os fonólitos sāo rochas de granulação fina, cor cinza e fratura lisa. Constituem-se de uma matriz composta principalmente por cristais sub-milimétricos de feldspato alcalino, nefelina e um pouco de egirina, sodalita e albita. Os dois primeiros minerais mostram-se frequuentemente alterados para natrolita. A egirina, no Morro do Tributo, apresenta crescimento poiquilítico de dimensáo centimétrica, o que dá à rocha aspecto mosqueado. SCHEIBE et al. (1984) apresentam a mineralogia e a paragênese destas rochas, destacando a presença de minerais raros, tais como eudialita, neptunita, lavenita e astrofilita.

Os fonólitos porfiríticos sło rochas de matriz afanítica com textura tranquitóide, constituídas por feldspato alcalino, nefelina e, subordinadamente, por egirina e sodalita. Fenocristais prismáticos de feldspato alcalino, mostrando geminaçđo Carlsbad, e de nefelina idiomórfica, mostrando clivagem basal conspicua, atingem dimensøes milimétricas e mostram-se muitas vezes alterados para natrolita e cancrinita.

Os nefelina-sienitos profiríticos apresentam essencialmente a mesma mineralogia dos fonólitos, mas a matriz é fanerítica e os fenocristais centimétricos. No plano mineralógico, a diferença marcante é a presença de piroxênio cálcico em muito maior quantidade que egirina (SCHEIBE et al., 1984).

Os pequenos corpos de analcita-traquito constituem-se principalmente por feldspato alcalino e analcita e, do ponto de vista químico, sđo rochas mais ácidas que as anteriormente descritas.

\section{Relevo}

A região de Lages situa-se a altitudes mé dias em torno de $900 \mathrm{~m}$, isto é, encontra-se um pouco rebaixada em relaçáo aos altos da escarpa do Segundo Planalto da Serra Geral que, na 
região, atingem altitudes sempre superiores a $1000 \mathrm{~m}$. No entanto, na área do complexo encontram-se elevaços, sobretudo relacionadas aos corpos alcalinos, que podem chegar até 1220 $\mathrm{m}$, como é o caso do Morro do Tributo. As Serras da Chapada, Cadeado e Cerro Alto estão a altitudes de cerca de $1000 \mathrm{~m}$ e a Serra da Farinha Seca, parcialmente constituída de diabásio, tem seus picos a $960 \mathrm{~m}$.

A drenagem principal é representada pelo rio Canoas que ocorre no limite norte do macico no sentido leste-oeste. Seus principais afluentes săo os rios dos f́ndios e do Tributo, cujas cabeceiras estão na porção sul do maciço. Localmente a drenagem é controlada pelos afloramentos das rochas alcalinas ou por pequenas estruturas dômicas relacionadas provavelmente a corpos alcalinos em profundidade (LINDSTAEDT, 1972); neste caso, o padrão é radial e anelar. Na parte norte da área observa-se um padrao paralelo na drenagem que aí é controlada por sistemas de falhamentos retilíneos.

\section{Clima e Vegetaçāo}

Dados compilados por SCHEIBE (1979) indicam para a regiāo de Lages temperaturas médias anuais em torno de $15^{\circ} \mathrm{C}$, oscilando entre 26 e $28^{\circ} \mathrm{C}$ (média das máximas em janeiro) e $-8^{\circ} \mathrm{C}$ (mínima absoluta em julho).

A precipitação média anual é da ordem de $1500 \mathrm{~mm}$, bem distribuídos durante 0 ano todo, mas ligeiramente concentrados nos meses de agosto, setembro e outubro, sendo os meses mais secos os de maio, junho e julho.

Em vista destes dados, o clima da área classifica-se no tipo Cfb de Koeppen: mesotérmico, sempre úmido, com verōes frescos.

A vegetaçẳo é principalmente de dois tipos (ALONSO, 1977 apud SCHEIBE, 1979): floresta sub-caducifolia subtropical com Araucaria angustifolia e campo. Segundo este autor, a floresta estaria em equilibrio com o clima atual, enquanto que as áreas de campo seriam remanescentes de um clima passado, de caráter mais seco.

$\mathrm{Na}$ parte norte da área, sobretudo na Serra da Farinha Seca, grandes extensōes de terra foram desmatadas e reflorestadas com Pinus eliotti.

\section{ALTERAÇÃO DAS ROCHAS ALCALINAS DA SERRA DA FARINHA SECA E FORMACุĀO DA JAZIDA DE BAUXITA}

As jazidas de bauxita do distrito de Lages estశo praticamente restritas aos topos da Serra da Farinha Seca. Foram, portanto, os fonólitos porfiríticos que, em condiçōes adequadas de drenagem, responderam aos agentes intempericos transformando-se em material essencialmente composto por hidróxidos de alumínio. Para o esclarecimento do mecanismo destas transformaçóes, foram descritos e amostrados dezenas de poços e algumas trincheiras em diferentes posiçoes topográficas. Estas amostras foram analisadas quimicamente e seu conteúdo mineralógico foi determinado. A interpretação dos resultados obtidos é o principal objetivo deste capitulo.

\section{As Facies de Alteraçāo Presentes}

Distinguem-se nos perfis de alteraçāo quatro diferentes tipos de materiais que, do ponto de vista macroscópico, serđo descritos a seguir.

a Rocha fresca: fonólito porfirítico já caracterizado no capítulo anterior. Esta facies é dificilmente encontradas de forma maciça em profundidades inferiores a vinte metros. Os exemplares descritos provém de fragmentos decimétricos arredondados, compostos por um núcleo de rocha sa envolvido por um córtex de material alterado. O material como um todo faz parte do horizonte aqui denominado rocha alterada.

b. Rocha alterada: trata-se de material rochoso, mas de coesao e densidade inferiores às da rocha sa. Macroscopicamente, 0 aspecto que mais chama a atençáo é a mudança de cor, que passa de um cinza escuro esverdeado para tons de cinza claro, bege e amarelo. Os fenocristais de nefelina e feldspato alcalino são bem visíveis, às vezes ainda frescos, às vezes já trans: formados num material pulverulento esbranquiçado. A transiçāo da rocha fresca para a rocha alterada se dá gradualmente, expressfo de um processo que tem início nas fraturas da rocha, isolando núcleos frescos e que, à medida em que se intensifica, atinge e homogeiniza todo o horizonte.

c. Bauxita: material duro, coeso, áspero ao tato, de coloração predominantemente amarelada. $\hat{E}$ leve, poroso e conserva geralmente bem a estrutura da rocha. As vezes apresenta-se recortado por veios brancos sub-milimétricos de gibbsita pura. Não foram observadas as texturas ooliticas descritas por SZUBERT \& VERGARA (1975). A bauxita pode ocorrer diretamente em contato com a rocha alterada ou com os niveis argilosos descritos a seguir. De maneira geral, nos perfis onde ocorre bauxita, ela é predominante no topo do perfil. 
d. Argila: é una fácies geralmente friável, de granulaçato fina e de tonalidades róseas, ou esbranquiçadas. Às vezes são visíveis estruturas reliquiares da rocha. A densidade deste material é um pouco mais alta que a da bauxita. Apresenta freqüentemente concentraçס̄es enegrecidas de manganês sob, forma de manchas esparsas, películas atapetando superfícies de descontinuidade ou mesmo veios de dimensठ̌es milimétricas a até centimétricas.

\section{Distribuição das Facies no Espaço}

Na Serra da Farinha Seca foram selecionadas quatro áreas, em diferentes contextos topográficos, com a finalidade de examinar a dependência deste fator na estruturação dos perfis de al teração.

a. Area Parisotto: nesta área (Fig. 2) foram descritas duas topossequências (I e II), abrangendo dez popos. A distribuição das facies na topossequência I é mostrada na Figura 3, onde se vê claramente que a bauxita só aparece nas porçбes mais elevadas do relevo, intercalada com material argiloso. Na porçáo superior da encosta, representada pelo poço I-4, ocorre um delgado nível de bauxita de origem coluvionar sobre a rocha alterada. Mais abaixo, nos setores onde a erosão predomina sobre a alteração, ocorre rocha alterada sem qualquer cobertura. $\mathrm{Na}$ topossequência II ( $\mathrm{Fig}, 4$ ), os poços III-2e II-3, em posiç̃o de topo, apresentam perfís bauxíticos in situ; o perfil II-1, em posição alta na encosta, compoe-se de bauxita in situ sobre rocha alterada e é recoberto por cerca de um metro de bauxita coluvionar; o perfil II -4 , em posiçăo de encosta íngreme, $e$ formado essencialmente por bauxita coluvionar sobre rocha alterada.

b. Area Pelanda: esta área (Fig. 2) situa-se em posição topográfica de topo e constitui-se num depósito de bauxita que vem sendo lavrado atualmente. Foram amostradas duas frentes de lavra (IV-1 e LG-III) e dois poços (IV -2 e V-1). Nas frentes de lavra aflora bauxita com intercalaçóes eventuais de material argiloso. Nos poços, onde a rocha alterada não foi atingida apesar das profundidades de $11 \mathrm{e} 21 \mathrm{~m}$, ocorre bauxita mais ou menos misturada com argila (Fig. 5).

c. Area Momm: como na área Pelanda, existe aqui (Fig. 2) um pequeno depósito em fase de lavra. O perfil amostrado (Fig. 6) mostra bauxita recoberta por um nível mais argiloso em contato com a rocha alterada.

d. Área Faxinal: esta área (Fig. 2) compreende três manchas de rochas alcalinas no limite oeste da Serra da Farinha Seca. É uma área mais baixa que as anteriores e os dois poços examinados encontram-se próximos do nível de drenagem local. Nestes poços nāo há bauxita, sendo a rocha alterada diretamente recoberta por uma camada de argila (Fig. 7). É característico desta área o fenômeno de concrecionamento incipiente das argilas.

$\mathrm{Da}$ descrição acima ficam caracterizados três tipos de sítios topográficos com seus respectivos perfis:

- topos com bauxita in situ, mais ou menos intercalada com material argiloso; representam sítios bem drenados onde a alteraçáo, de tendência à alitização, prevalece sobre a erosđa;

- encostas ingremes, onde a erosão compete com a alteração, resultando em perfis pouco desenvolvidos, recobertos ou não por um colúvio de pequena espessura; a tendência da alte. ração é em direção à monossialitização, provavelmente em decorrência da menor infiltraçāo de água nestes sítios, em compáraçao com os topos aplainados;

- baixadas sem ocorrências de bauxita; aqui a alteração prevalece sobre a erosão, como nos topos, mas tem caráter de monossialitização em conseqüência do relativo impedimento da drenagem interna dos perfis devido à proximidade do nível d'água.

\section{Mineralogia das Facies}

No intuito de caracterizar as fases presentes em cada tipo de material, foram efetuadas determinaçōes mineralógicas por difração de raios X para cerca de uma centena de amostras e por análise termo-diferencial para algumas amostras selecionadas. Foram submetidas à difração de raios X não só amostras totais moídas mas, em alguns casos, fraçōes granulométricas selecionadas da amostra original, principalmente a fração argila $(<2 \mu \mathrm{m})$. Também foram analisados aos raios $\mathrm{X}$ veios ou concentraçōes de certos minerais que puderam ser distinguidos macroscopicamente e separados manualmente.

Quase todas as amostras estudadas foram laminadas, após tratamento com resina sintéti$\mathrm{ca}$, em caso de necessidade de endurecimento prévio. As lâminas foram examinadas ao microscópio óptico, onde puderam ser observadas as relaçōes genéticas entre os minerais hipógenos e aqueles resultantes da alteração supérgena.

a. Composiçấo mineralógica de cada horizonte. Os fonólitos porfiríticos da Serra da Farinha Seca já foram descritos, do ponto de vista petrográfico, por LINDSTAED (1972), SZU. BERT \& VERGARA (1975) e por SHEIBE et al. (1984). No ítem II.1.b foram apresenta- 
dos dados sobre a composição mineralógica e a textura destas rochas.

$\mathrm{O}$ in ício da alteração supérgena é evidenciado pelo aparecimento da goethita que substitui as egirinas, imprimindo uma tonalidade alaranjada a esse mineral, a partir do centro do prisma, em direção às bordas. É comum a ocorrência, na rocha alterada, de egirina com as extremidades verdes e, portanto, frescas e o centro totalmente substituído por goethita. Com relação aos feldspatos, seja como fenocristais, seja como pequenas ripas na matriz, o padrão de corrosao é totalmente outro: é ao longo das clivagens e fraturas que ocorre a transformação feldspato-gibbsita. Não foi possível observar o início da alteraçáo da nefelina provavelmente porque esse fenômeno se completa rapidamente, tendo como resultado também a gibbsita. Os horizontes de rocha alterada sฮ́o freqüentemente recortados por veios sub-milimétricos de gibbsita bem cristalizada, que cresce perpendicularmente às paredes das fraturas.

A evolução exposta acima descreve a rocha alterada como produto do processo de alitização dos minerais primários. No entanto, em certas condiçōes topográficas, conforme já foi visto no item 2, a rocha fresca pode evoluir para material argiloso, e, neste caso, o aspecto das lâminas delgadas da rocha alterada é bem diferente. Enquanto que no caso anterior a estrutura original da rocha era preservada, através da epigenização dos feldspatos e nefelina por gibbsita, aqui os minerais primários dฮ̃o lugar a uma massa de argila e goethita que não lembra em nada a textura traquitóide original da rocha. Os fenocristais de feldspato apresentam se man. chados e invadidos, preferencialmente ao longo de seus planos de clivagem, por um material isó. tropo. Veios de material argiloso microcristalino de birrefringência bem baixa aparecem recortando as amostras. O controle difratométri. co da rocha alterada indica que a argila presente no início da alteraçåo é principalmente a halloisita $4 \mathrm{H}_{2} \mathrm{O}$.

Os difratogramas das bauxitas revelam que este material é constituído essencialmente por gibbsita e goethita. Nos diagramas de ATD aparecem bem caracterizados os picos endotérmicos da gibbsita: um pico principal a $310^{\circ} \mathrm{C}$ e dois subsidiários no intervalo de 250 a $300^{\circ} \mathrm{C}$ e a $525^{\circ} \mathrm{C}$. Aparece também o pico endotérmico característico da goethita a $350^{\circ} \mathrm{C}$, o que significa, segundo MACKENZIE (1957) que este mineral apresenta-se bem cristalizado. Quando a fração argila foi separada, ela mostrou aos raios $\mathrm{X}$, de maneira sistemática, além da presença de gibbsita, a presença de boehmita, donde se conclui que este mineral deve estar sempre presente nas bauxitas, em pequenas quantidades e em gra nulaçao muito fina. Nesta fração aparecem ainda traços de um mineral de argila que, na maior parte dos casos, é caolinita. A caolinita foi identificada através de seus espaçamentos interplanares principais de 7.15 e a $3.56 \mathrm{~A}$. Distingue-se da halloisita $2 \mathrm{H}_{2} \mathrm{O}$ por nฮ̃o expandir o espaçamento basal a $10 \mathrm{~A}$ quando tratada com formamida (ROSS et al., 1983). Com a finalidade de pesquisar melhor a composição dos óxidos de ferro, algumas amostras de bauxita foram submetidas a tratamento com soda a quente, que colocou em solução os silicatos secundários e os óxidos de alumínio. $O$ residuo deste ataque evidenciou aos raios $\mathrm{X}$ quase que unicamente goethita, acompanhada por traços de zircão $e$ anatásio. Em algumas amostras, pequenos picos correspondentes a distâncias interplanares de $3.66 \mathrm{~A}$ e $2.51 \mathrm{~A}$ sugeriram a presença de hematita. Se este mineral de fato estiver presente, $\hat{e}$ em quantidades baixas. Quanto à textura, nas bauxitas a gibbsita apresenta um aspecto rendado que lembra o padrao de alteração dos feldspatos, revelado nas amostras de rocha alterada. A goethita é microcristalina e aparece acumulada em pequenos prismas, substituindo pseudomorficamente a egirina, o que contribui para que a estrutura original da rocha seja reconhecível. 0 material como um todo é recortado por veios de gibbsita bem cristalizada.

As argilas constituem o material de observação mais difícil ao microscópio óptico. Nestas amostras vêem-se dificilmen te traços da estrutura original da rocha; o material argiloso parece muito misturado com os hidróxidos de ferro. Uma feiçđo característica do horizonte argiloso é a concentração de óxidos de manganês misturados com argila, seja em veios, seja em acumulaçoes mais equidimensionais. Dados difratométricos indicaram que a argila presente é ora caolinita, ora halloisita, ora ambas; o óxido de manganês é a litioforita e o óxido de ferroé a goethita. Nos diagramas de ATD a halloisita é representada por um pico endotérmico em torno de $100^{\circ} \mathrm{C}$ e outro a $560^{\circ} \mathrm{C}$. O pico exotérmico a $980^{\circ} \mathrm{C}$ não foi pesquisado devido a limitaçōes da aparelhagem.

Do que foi exposto acima, parece claro que a natureza do argilomineral varia em funçฐ̃o das fases que o acompanham. Assim, de 60 amostras onde ele foi constatado, sua distribujção se dá conforme a Tabela 1.

A halloisita parece, portanto, característica das fases iniciais da alteraçāo, enquanto que a caolinita acompanha preferencialmente materiais mais evoluídos como a bauxita. Aliás, mesmo quando a caolinita é encontrada no material argiloso, ela ocorre sempre associada à gibbsita. 
Tabela 1 - Distribuiçđo da Caolinita e da Halloisita $4 \mathrm{H}_{2} \mathrm{O}$ na Rocha Alterada, Argila e Bauxita

\begin{tabular}{lcc}
\hline & Caolinita & Halloisita $4 \mathrm{H}_{2} \mathrm{O}$ \\
\hline Rocha alterada & $12 \%$ & $88 \%$ \\
Argila & $43 \%$ & $57 \%$ \\
Bauxita & $75 \%$ & $25 \%$ \\
\hline
\end{tabular}

A presença de halloisita na raiz dos perfis de alteraçăo em zona tropical já foi constatada por FUJIMORI (1975) nas alteritas de Salvador e por MONIZ (1969) em Poços de Caldas.

b. Filiaçбes mineralógicas. A goe thita provém essencialmente dos piroxênios, por lixiviaçăo do sódio, cálcio, magnésio e silicio, restan. do apenas o ferro que se cristaliza como óxido hidratado. Um processo incipiente de desidrata. çđ̃o da goethita pode ter originado a hematita. As equaçōes abaixo indicam estas transforma. çōes:

$$
\begin{aligned}
& \mathrm{NaFeSi}_{2} \mathrm{O}_{6}+5 \mathrm{H}_{2} \mathrm{O} \rightleftharpoons \\
& \mathrm{Na}^{+}+\mathrm{OH}^{-}+2 \mathrm{H}_{4} \mathrm{SiO}_{4}+\mathrm{FeOOH} \\
& 2 \mathrm{FeOOH} \rightleftharpoons \mathrm{Fe}_{2} \mathrm{O}_{3}+\mathrm{H}_{2} \mathrm{O}
\end{aligned}
$$

$\mathrm{O}$ anatásio deriva provavelmente da titanita, que ocorre na rocha associada à egirina.

A gibbsita é formada diretamente pela alteraçđo do feldspato alcalino e da nefelina por dessilicificação, lixiviaçāo das bases e cristalizaçăo in situ do aluminio. Neste caso, a perda de matéria é significativa, do que decorre a gênese de um material muito poroso, cuja densidade aparente pode chegar a ser inferior a um. Este fenòmeno está expresso pela equação abaixo, que vem acompanhada dos volumes molares das fases envolvidas:

$$
\begin{aligned}
& \mathrm{KAlSi}_{3} \mathrm{O}_{8}+8 \mathrm{H}_{2} \mathrm{O} \rightleftharpoons \\
& 108 \mathrm{ec} \\
& \mathrm{K}^{+}+\mathrm{OH}^{-}+3 \mathrm{H}_{4} \mathrm{SiO}_{4}+\mathrm{Al}(\mathrm{OH})_{3} \\
& 32 \mathrm{cc}
\end{aligned}
$$

Os veios de gibbsita que recortam os niveis alterados têm certamente outra origem. Devem ter sido formados por precipitação de $\mathrm{Al}(\mathrm{OH})_{3}$ a partir de soluçōes que percolaram o perfil de alto a baixo. Esse alumínio em solução deve ter sido proveniente da desestabilização de minerais aluminosos do topo do perfil, sob influência da matéria orgânica que abaixa o $\mathrm{pH}$ do meio e fornece fons complexantes.
Com o aumento do $\mathrm{pH}$ nos niveis inferior do perfil, ocorrem condiçб̄es propicias para a precipitação do $\mathrm{Al}(\mathrm{OH})_{3}$.

A boehmita deriva da gibbsita por desidrataçă:

$$
\mathrm{Al}_{2} \mathrm{O}_{3} \cdot 3 \mathrm{H}_{2} \mathrm{O} \Rightarrow \mathrm{Al}_{2} \mathrm{O}_{3} \cdot \mathrm{H}_{2} \mathrm{O}+2 \mathrm{H}_{2} \mathrm{O}
$$

A paragênese gibbsita-boehmita é estável na ausência de $\mathrm{H}_{2} \mathrm{O}$ como uma fase independente (CHESWORTH, 1972). Isso explica porque a boehmita é principalmente encontrada nos niveis superiores dos perfis, onde a umidade é menos permanente.

O problema da gênese da caolinita e da halloisita $4 \mathrm{H}_{2} \mathrm{O}$ é o mais complexo e não pôde ser inteiramente esclarecido ao nivel deste trabalho. No entanto, observaçōes micromorfológicas e a distribuiçāo destes dois minerais nas diferentes facies de alteração sugerem as seguintes tentativas de interpretação:

- a halloisita provém diretamente da alteraça do feldspato alcalino e da nefelina em condiçбes de drenagem insuficiente para lixiviação total da silica, segundo as equaçбes:

$$
\begin{gathered}
2 \mathrm{KAISi}_{3} \mathrm{O}_{8}+13 \mathrm{H}_{2} \mathrm{O} \rightleftharpoons \\
\mathrm{Al}_{2} \mathrm{Si}_{2} \mathrm{O}_{5}(\mathrm{OH})_{4} \cdot 2 \mathrm{H}_{2} \mathrm{O}+4 \mathrm{H}_{4} \mathrm{SiO}_{4}+2 \mathrm{~K}^{+}+2 \mathrm{OH} \\
2 \mathrm{NaAlSiO}_{4}+5 \mathrm{H}_{2} \mathrm{O} \rightleftharpoons \\
\mathrm{Al}_{2} \mathrm{Si}_{2} \mathrm{O}_{5}(\mathrm{OH})_{4} \cdot 2 \mathrm{H}_{2} \mathrm{O}+2 \mathrm{Na}^{+}+2-\mathrm{OH}
\end{gathered}
$$

Esta hipótese é sustentada pela observação ao microscópio dos fenocristais de feldspato invadidos ao longo de suas clivagens pela halloisita. É também sugerida pela estreita associaçáo rocha al terada-hallosita, conforme mostra a Tabela 1 .

- a caolinita origina-se pela ressilicificaçđo da gibbsita; este último mineral, ao entrar em contato com soluçóes ricas em sulica proveniente do ataque dos minerais primários, reage com ela e disto resul ta a cristalização da caolinita, segundo a equação: 


$$
\begin{aligned}
& 2 \mathrm{KAlSi}_{3} \mathrm{O}_{8}+13 \mathrm{H}_{2} \mathrm{O} \rightleftharpoons \\
& \mathrm{Al}_{2} \mathrm{Si}_{2} \mathrm{O}_{5}(\mathrm{OH})_{4} \cdot 2 \mathrm{H}_{2} \mathrm{O}+4 \mathrm{H}_{4} \mathrm{SiO}_{4}+ \\
& 2 \mathrm{~K}^{+}+2 \mathrm{OH}^{-}
\end{aligned}
$$

Um argumento a favor desta hipótese é o fato de a caolinita ocorrer sempre associada à gibssita, seja no horizonte argiloso, seja na bauxita. No entanto, ao microscópio, náo é possível observar a substituição da gibbsita pela caolini. ta. Isto pode ser devido à fina granulação da gibbsita e ao fenômeno de destruição completa das estruturas primitivas, acompanhado da mistura da caolinita com ferro. A demonstraçåo experimental desta possibilidade está exposta em KIMPE et al. (1964).

Evidências da gênese direta da gibbsita a partir de silicatos primários e de formaçáo de caolinita por ressilicificação de gibbsita são mencionados na literatura por diversos autores, entre os quais GOLDMAN \& TRACEY Jr (1946), GORDON et al. (1958), DELVIGNE (1965), MONIZ (1969), MONIZ et al. (1972) e ALMEIDA (1977).

Quanto à ordem de al teraçăo dos minerais, evidências micromorfológicas revelaram que entre os félsicos é a nefelina que se altera primeiro, mais ou menos ao mesmo tempo que a egirina. O feldspato alcalino é o último mineral a se alterar.

Uma última menção a ser feita neste item diz respeito à possibilidade de existência de fases amorfas intermediárias entre os minerais primários e os minerais secundários. De difícil observação ao microscópio e insusceptível de tratamento aos raios X, estas fases só serđo evidenciadas por ataques químicos parciais e serão tratadas mais adiante.

\section{Quimismo}

Foram analisadas 102 amostras para $\mathrm{H}_{2} \mathrm{O}^{+}, \mathrm{SiO}_{2}, \mathrm{Al}_{2} \mathrm{O}_{3}, \mathrm{Fe}_{2} \mathrm{O}_{3}, \mathrm{Na}_{2} \mathrm{O}, \mathrm{K}_{2} \mathrm{O}$, $\mathrm{CaO}, \mathrm{MgO}$ e $\mathrm{MnO}$, das quais 40 também para $\mathrm{TiO}_{2}$. A sílica foi dosada por gravimetria, o titânio por colorimetria e os demais elementos por absorçāo atômica. Estas rochas representam materiais encontrados nos vários níveis do perfil, da rocha à bauxita.

Para a dosagem das fases amorfas foram selecionadas 4 amostras de várias posiçōes do perfil de alteraçāo e procedeu-se segundo o método preconizado por SEGALEN, 1968.

O cálculo do balanço geoquímico foi efetuado para 96 amostras, através da avaliação da quantidade de cada óxido presente em $100 \mathrm{cc}$ da amostra, o que é obtido multiplicando o teor ponderal do oxido pela densidade aparente da amostra (MILLOT \& BONIFAS, 1955).

\section{Composição química da rocha fresca}

A Tabela 2 mostra a composição quimica de 7 exemplares de fonólitos porfiríticos. Sø̃o roch as intermediárias, ricas em $\mathrm{Al}_{2} \mathrm{O}_{3}$ e álcalis e com baixo teor de ferro. Nestes fonólitos o teor de $\mathrm{Na}_{2} \mathrm{O}$ é sempre bem elevado, podendo superar $10 \%$, o teor $\mathrm{em} \mathrm{K}_{2} \mathrm{O}$ é mais baixo, mas situa-se sempre para além dos $4 \%$ O teor de $\mathrm{CaO}$ raramente atinge $2 \%$.

Com relaçăo aos elementos traços, os poucos dados disponiveis na literatura e presentes na Tabela 2 indicam que o $\mathrm{La}, \circ \mathrm{Ga}$ e $\circ \mathrm{Zr}$ ocorrem em quantidades semelhantes ao clarke, - $\mathrm{Y}, \mathrm{V}$ e $\mathrm{Zn}$ em quantidades inferiores e o Be, $\mathrm{Pb}, \mathrm{Nb}, \mathrm{Mo}, \mathrm{Sr}, \mathrm{Ba}$, e Cl em quantidades superiores.

Comparando com as rochas alcalinas de Poços de Caldas (ALMEIDA, 1977), os fonólitos da Farinha Seca apresentam 2 diferenças marcantes; a razão $\mathrm{Na}_{2} \mathrm{O} / \mathrm{K}_{2} \mathrm{O}$ mais alta e oferro total mais baixo. No entanto, os fonólitos de ambos os maciços mostram deficiência em Al em relação à soma $\mathrm{Na}+\mathrm{K}$ em número de molé. culas, podendo ser, portanto, classificados como agpaiticos (SCHEIBE et al., 1984).

\section{Composição química dos niveis alterados}

O critério utilizado para definir os limites entre rocha fresca/alterada, material argiloso e bauxita foi o seguinte:

rocha fresca/alterada material argiloso

$$
\mathrm{SiO}_{2}>15 \% \text { e } \mathrm{Na}_{2} \mathrm{O}+\mathrm{K}_{2} \mathrm{O}>1,5 \%
$$

$$
\mathrm{SiO}_{2}>15 \% \text { e } \mathrm{Na}_{2} \mathrm{O}+\mathrm{K}_{2} \mathrm{O}<1,5 \%
$$

bauxita

$$
\mathrm{SiO}_{2}<15 \% \text { e } \mathrm{Na}_{2} \mathrm{O}+\mathrm{K}_{2} \mathrm{O}<1,5 \%
$$

$A$ rocha fresca/alterada corresponde a um material composto de mais de $10 \%$ em peso de minerais primários (feldspato e nefelina, principalmente) e por halloisita e/ou gibbsita. O material argiloso contém menos de $10 \%$ em peso de minerais primários e mais de $35 \%$ de halloisita ou caolinita; pode conter gibbsita. A bauxita é um material composto principalmente por gibbsita, com menos de $10 \%$ de minerais primários e menos de $35 \%$ de caolinita.

As Tabelas, 3,4 e 5 mostram a composiçāo química de cada facies expressa através da média, desvio padrâo, máximo e mínimo para cada óxido e para a densidade aparente. 
TABELA 2 - Composição Química dos Fonólitos Porfiríticos \% em peso dos óxidos

\begin{tabular}{|c|c|c|c|c|c|c|c|c|c|}
\hline 80 & $L A-O I^{(1)}$ & $L A \cdot 02^{(1)}$ & $M C M \cdot 1^{(2)}$ & $11.15^{(3)}$ & $15.6^{(3)}$ & II $3.5^{(3)}$ & III $2 . x^{(3)}$ & Media & Popos (4) \\
\hline $\mathrm{SiO}_{2}$ & 51.60 & 54.50 & 49.49 & 50.20 & 49.90 & 49.50 & 52.20 & 51.05 & 53.50 \\
\hline $\mathrm{TiO}_{2}$ & 0.32 & 0.45 & 0.03 & n.d. & n.d. & n.d. & n.d. & 0.27 & 0.76 \\
\hline $\mathrm{Al}_{2} \mathrm{O}$ & 22.10 & 22.20 & 22.33 & 23.32 & 22.66 & 24.07 & 23.69 & 22.91 & 20.10 \\
\hline $\mathrm{Fe}_{2} \mathrm{O}_{3} *$ & 3.36 & 3.16 & 3.39 & 3.40 & 3.10 & 3.20 & 2.80 & 3.20 & 6.01 \\
\hline MnO & 0.19 & 0.10 & 0.20 & 0.21 & 0.20 & 0.20 & 0.17 & 0.18 & 0.22 \\
\hline $\mathrm{MgO}$ & 0.36 & 0.39 & 0.34 & 0.17 & 0.16 & 0.15 & 0.11 & 0.24 & 0.28 \\
\hline $\mathrm{CaO}$ & 1.60 & 2.00 & 2.06 & 1.62 & 1.69 & 1.55 & 1.02 & 1.65 & 1.72 \\
\hline $\mathrm{K}_{2} \mathrm{O}$ & 5.23 & 7.37 & 5.57 & 4.78 & 4.45 & 4.75 & 4.50 & 5.24 & 7.79 \\
\hline $\mathrm{Na}_{2} \mathrm{O}$ & 9.22 & 6.52 & 10.43 & 7.28 & 11.13 & 11.78 & 8.98 & 9.33 & 6.59 \\
\hline $\mathrm{P}_{2} \mathrm{O}_{5}$ & 0.07 & 0.11 & 0.10 & n.d. & n.d. & n.d. & n.d. & 0.09 & 0.13 \\
\hline $\mathrm{H}_{2} \mathrm{O}^{+}$ & 5.27 & 2.31 & 0.94 & 6.40 & 4.70 & 4.00 & 3.60 & 3.88 & 1.69 \\
\hline densidade & n.d. & n.d. & 2.41 & 2.41 & 2.49 & 2.49 & 2.72 & 2.50 & \\
\hline \multicolumn{10}{|c|}{ ppm dos elementos } \\
\hline $\mathrm{Cu}$ & & & 5 & & & & ne & +2 & 10 \\
\hline $\mathrm{Zr}_{\mathrm{r}}$ & 295 & 220 & 112 & & & & & $x^{2}$ & \\
\hline $\begin{array}{l}\mathrm{Y} \\
\mathrm{V}\end{array}$ & . & & $\begin{array}{r}5 \\
10\end{array}$ & & & & ntin & 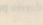 & 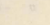 \\
\hline $\mathrm{Be}$ & & & 20 & & & & & & \\
\hline $\mathrm{Pb}$ & & & 52 & & & & . & & 22 \\
\hline $\mathrm{Nb}$ & & & 112 & & & & & & \\
\hline Mo & & & 5 & & & 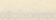 & $-2 x$ & 14: 1 & \\
\hline $\begin{array}{l}\mathrm{Zn} \\
\mathrm{La}\end{array}$ & 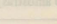 & 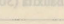 & $\begin{array}{r}\mathrm{tr} \\
20\end{array}$ & $1+4=$ & L & & & & 195 \\
\hline $\mathrm{Ga}$ & \multirow{3}{*}{$\begin{array}{l}1100 \\
1000\end{array}$} & & 14 & & & & & & \\
\hline $\mathrm{Sr}$ & & 2200 & & . & & 1015 & & & 1030 \\
\hline $\mathrm{Ba}$ & & $\begin{array}{l}1600 \\
2000\end{array}$ & & & & 26140 & A & & - \\
\hline
\end{tabular}

(1) Análise feita na Geosol (SCHEIBE, com. pessoal)

(2) Análise citada em LINDSTAED (1972)

(3) Análises feitas no Lab. Geoquímica - USP

(4) Média de 2 análises de fonólito citada em ALMEIDA (1977)

* Fe total calculado como $\mathrm{Fe}_{2} \mathrm{O}_{3}$

TABELA 3 - Composição Química (\% em peso) da Facies Rocha Fresca/Alterada (51 amostras)

\begin{tabular}{lrrrr}
\hline & Min & Max & $\bar{x}$ & $\sigma$ \\
\hline densidade & 0,99 & 2,72 & 1,67 & 0,41 \\
$\mathrm{H}_{2} \mathrm{O}^{*}$ & 3,60 & 23,07 & 12,16 & 3,89 \\
$\mathrm{SiO}_{2}$ & 16,49 & 52,20 & 42,71 & 7,84 \\
$\mathrm{Al}_{2} \mathrm{O}_{3}$ & 22,33 & 50,87 & 33,57 & 6,14 \\
$\mathrm{Fe}_{2} \mathrm{O}_{3}$ & 3,00 & 11,87 & 4,20 & 0,80 \\
$\mathrm{Na}_{2} \mathrm{O}$ & 0,07 & 6,36 & 1,98 & 2,92 \\
$\mathrm{~K}_{2} \mathrm{O}$ & 0,75 & 2,06 & 4,39 & 1,27 \\
$\mathrm{CaO}$ & 0,04 & 1,00 & 0,46 & 0,46 \\
$\mathrm{MgO}$ & 0,03 & 0,66 & 0,18 & 0,16 \\
$\mathrm{MnO}$ & 0,05 & & 0,27 & 0,11 \\
\hline
\end{tabular}

Min - valor mínimo

Máx - valor máximo

$\bar{x} \quad-$ média

$\sigma$ - desvio padrão 
TABELA 4 - Composição Quimica (\% em peso) da Facies Material Argiloso (21 amostras)

\begin{tabular}{lrrrr} 
& Min & Max & \multicolumn{1}{c}{} & \multicolumn{1}{c}{$\sigma$} \\
\hline densidade & 0.98 & 1.75 & 1.35 & 0.25 \\
$\mathrm{H}_{2} \mathrm{O}^{*}$ & 14.57 & 25.25 & 19.05 & 3.33 \\
$\mathrm{SiO}_{2}$ & 15.49 & 41.96 & 30.61 & 8.47 \\
$\mathrm{Al}_{2} \mathrm{O}_{3}$ & 37.69 & 51.30 & 44.01 & 4.76 \\
$\mathrm{Fe}_{2} \mathrm{O}_{3}$ & 2.24 & 7.89 & 5.03 & 1.71 \\
$\mathrm{Na}_{2} \mathrm{O}$ & 0.01 & 0.36 & 0.17 & 0.11 \\
$\mathrm{~K}_{2} \mathrm{O}$ & 0.04 & 1.44 & 0.41 & 0.42 \\
$\mathrm{CaO}$ & 0.01 & 0.72 & 0.19 & 0.18 \\
$\mathrm{MgO}$ & 0.02 & 0.39 & 0.12 & 0.19 \\
$\mathrm{MnO}$ & 0.04 & 3.31 & 0.39 & 0.68 \\
\hline
\end{tabular}

Min - valor mínimo

Máx - valor máximo

$\bar{x}$ - média

o - desvio padrato

TABELA 5 - Composiçåo Química (\% em peso) da Facies Bauxita (30 amostras)

\begin{tabular}{lrrrc}
\hline & Min & Max & \multicolumn{1}{c}{$\bar{c}$} & $\sigma$ \\
\hline densidade & 0.85 & 1.60 & 1.17 & 0.18 \\
$\mathrm{H}_{2} \mathrm{O}^{+}$ & 25.50 & 31.82 & 28.73 & 1.58 \\
$\mathrm{SiO}_{2}$ & 1.98 & 14.15 & 6.22 & 3.25 \\
$\mathrm{Al}_{2} \mathrm{O}_{3}$ & 53.25 & 61.84 & 58.08 & 1.94 \\
$\mathrm{Fe}_{2} \mathrm{O}_{3}$ & 3.14 & 8.52 & 6.19 & 1.41 \\
$\mathrm{Na}_{2} \mathrm{O}$ & 0.01 & 0.55 & 0.17 & 0.14 \\
$\mathrm{~K}_{2} \mathrm{O}$ & 0.01 & 0.44 & 0.11 & 0.13 \\
$\mathrm{CaO}$ & 0.04 & 0.43 & 0.20 & 0.10 \\
$\mathrm{MgO}$ & 0.01 & 0.18 & 0.05 & 0.05 \\
$\mathrm{MnO}$ & 0.02 & 1.09 & 0.19 & 0.28 \\
\hline
\end{tabular}

Min - valor mínimo

Máx - valor máximo

$\bar{x}$ - média

$\sigma$ - desvio-padrão

A facies rocha fresca/alterada tem composição nđo muito diferentes da média para as rochas frescas (Tabela 2), apresentando como característica marcante o grande empobrecimento em $\mathrm{Na}_{2} \mathrm{O}$ e $\mathrm{CaO}$ e $\mathrm{O}$ enriquecimento em $\mathrm{Al}_{2} \mathrm{O}_{3}$. $\mathrm{O}$ horizonte de material argiloso é composto essencialmente por silica e alumina e, subordinadamente, por ferro. Na bauxita, a alumina domina largamente sobre os outros óxidos e o teor $\mathrm{em} \mathrm{H}_{2} \mathrm{O}^{+}$bem elevado evidencia a presença de minerais fortemente hidratados.

\section{Tendências gerais da alteração}

Os dados químicos apresentados evidenciam que a alteraçáo dos fonólitos se đá com perda de $\mathrm{SiO}_{2}$ (intensa no caso da formação de bauxita e moderada no caso de material argiloso), perda intensa dos álcalis (em ambos os casos) e concentração de $\mathrm{Al}_{2} \mathrm{O}_{3}$ e $\mathrm{Fe}_{2} \mathrm{O}_{3}$ (mais intensa nas bauxitas). Esse comportamento dos elementos maiores é característico da alteração laterítica. 
Os dados da literatura referentes aos elementos - traços na argila e na bauxita (LINDS. TAED, 1972) mostram que a argila nāo parece se enriquecer em relação à rocha fresca em nenhum dos elementos dosados, enquanto que a bauxita mostra teores sensivelmente mais ele. vados que a rocha fresca em $\mathrm{Cu}, \mathrm{Zr}, \mathrm{Y}, \mathrm{V}$, $\mathrm{Nb}$ e $\mathrm{Ga}$.

Foram calculados os coeficientes de correlação Pearson entre as variáveis para 102 amos. tras, sendo os resultados apresentados na Tabela 6. Ê possível distinguir dois grupos de óxidos de comportamento geoquímico oposto: os residuais, $\mathrm{Fe}_{2} \mathrm{O}_{3}$ e $\mathrm{Al}_{2} \mathrm{O}_{3}$ (correlação positiva entre si e negativa com os demais) e os solúveis, $\mathrm{SiO}_{2}, \mathrm{Na}_{2} \mathrm{O}, \mathrm{K}_{2} \mathrm{O}, \mathrm{CaO}$ e $\mathrm{MgO}$ (correlação positiva entre si e negativa com os demais). $\mathrm{O} \mathrm{MnO}$ nāo apresenta correlaçōes significativas com nenhum outro elemento, mas seu comportamento é ligeiramente mais parecido com os solúveis que com os residuais. A densidade aparente, parâmetro que reflete sensivelmente o grau de alteraçđo, fica incluída no grupo dos solúveis. A água estrutural cresce de importância quanto mais evoluído é o material e compó o grupo dos residuais.

As relaçđes acima apontadas são claramente percebidas quando se projetam os coeficientes de correlação de cada variável em função dos coeficientes de correlação das 2 variáveis que apresentam entre si o mais alto coeficiente de correlação negativo (Fig. 8). No caso, são a sílica e a alumina que se comportam dessa forma (Fig. 9), o que é consequência do fato de serem esses 2 b́xidos os mais importantes de um conjunto de variáveis de soma constante e de eles apresentarem comportamento contrastante.

A composiçăo química das 3 facies consideradas foi expressa, em termos de $\mathrm{SiO}_{2}$, $\mathrm{Al}_{2} \mathrm{O}_{3}$ e $\mathrm{Fe}_{2} \mathrm{O}_{3}$, seus componentes principais, no diagrama triangular da Figura 10. Segundo os critérios propostos por SCHELLMANN (1981), para a conceituaçāo de laterizaçāo em diversos graus, fica claro a partir da análise do diagrama que as amostras de rocha fresca/alterada pertencem ao domínio da caolinização, as amostras de material argiloso são produto de laterização fraca e média, e, finalmente, as bauxitas representam um processo de laterização forte.

O estudo da distribuição dos teores dos principais óxidos em cada uma das facies consideradas evidenciou certas regularidades, com relaçāo aos parâmetros dispersão dos teores em torno da média e assimetria. A Tabela 7 mostra que para os elementos solúveis $\mathrm{SiO}_{2}$ e $\mathrm{K}_{2} \mathrm{O}$, cujas médias caem da rocha fresca/alterada para a bauxita, a assimetria da distribuição dos teo- res passa de acentuadamente negativa para acentuadamente positiva e a dispersão dos teores aumenta. No caso dos elementos pouco móveis, $\mathrm{Al}_{2} \mathrm{O}_{3}$ e $\mathrm{Fe}_{2} \mathrm{O}_{3}$, acontece o contrário: a distribuição passa de assimétrica bastante positi. va na rocha fresca/alterada para aproximadamente simétrica na bauxita e a dispersāo dos teores diminui.

As caudas das curvas referentes a $\mathrm{SiO}_{2} \mathrm{e}$ $\mathrm{K}_{2} \mathrm{O}$ na populaçāo das bauxitas representam teores mais altos que a moda, assim como as caudas referentes ao $\mathrm{Al}_{2} \mathrm{O}_{3}$ e $\mathrm{Fe}_{2} \mathrm{O}_{3}$ na mesma populaçao representam teores mais baixos que a moda. Essas feiçōes refletem complementarmente o mesmo fato, qual seja, o de restarem em poucas amostras de bauxitas núcleos que resistiram mais à alteraçāo. Por outro lado, a ausência de assimetria ou pequeno grau de assimetria, como constatado para as distribuiçóes do $\mathrm{Al}_{2} \mathrm{O}_{3}$ e $\mathrm{Fe}_{2} \mathrm{O}_{3}$ na bauxita, corresponde sempre a uma baixa dispersão de teores, conforme já assinalado por AHRENS (1966).

As regularidades que acabam de ser comentadas já tinham sido verificadas pela autora para a transiçáo dunito alterado - laterita com relaçáo às amostras do maciço ultramáfico de Santa Fé (OLIVEIRA, 1978) e é possivel que constituam uma feiçāo geral do processo de alteração supérgena das rochas, cujo significado mais profundo ainda nāo foi compreendido.

\section{Composição mineralógica das facies de alteração}

A Figura 11 representa um fragmento da topossequência $I$, composto pelos poços $I-2$, I-3 e I-4, para cujas amostras foi calculada a composiça mineralógica aproximada a partir da análise química e do conhecimento da composiçăo mineralógica obtido por difraçâo de raios $\mathrm{X}$.

Considerando-se que, para amostras de material argiloso e de bauxita, o aluminio, além de estar contido na halloisita e na gibbsita, também entra no retículo da goethita, foi necessário avaliar em que proporção isto acontece. Esta avaliação foi feita a partir da determinação do desvio do pico correspondente ao espaçamento d (111), segundo o que foi proposto por FITZPATRICK \& SCHWERTMANN (1982). Os resultados destas determinações, assim como as estimativas do grau de cristalinidade da goe. thita (expressa pela largura do pico 111 medida à meia altura) constam da Tabela 8 . A ańlise desta tabela mostra que na bauxita a goethita contém em média 23,3\% molar de $\mathrm{AlOOH}$, enquanto que a goethita que acompanha o material argiloso contém apenas $21,2 \%$ molar. 
TABELA 6 - Correlação entre os Óxidos (102 amostras)

\begin{tabular}{|c|c|c|c|c|c|c|c|c|c|}
\hline $\mathrm{H}_{2} \mathrm{O}^{+}$ & $-0,62$ & & & & & & & & \\
\hline $\mathrm{SiO}_{2}$ & $+0,56$ & $-0,98$ & & & & & & & \\
\hline $\mathrm{Al}_{2} \mathrm{O}_{3}$ & $-0,64$ & $+0,98$ & $-0,98$ & & & & & 2 & \\
\hline $\mathrm{Fe}_{2} \mathrm{O}_{3}$ & $-0,42$ & $+0,67$ & $-0,70$ & $+0,63$ & & & & & \\
\hline $\mathrm{Na}_{2} \mathrm{O}$ & $+0,78$ & $-0,53$ & $+0,42$ & $-0,53$ & $-0,34$ & & & & \\
\hline $\mathrm{K}_{2} \mathrm{O}$ & $+0,56$ & $-0,84$ & $+0,81$ & $-0,86$ & $-0,51$ & $+0,45$ & & & \\
\hline $\mathrm{CaO}$ & $+0,71$ & $-0,45$ & $+0,35$ & $-0,47$ & $-0,23$ & $+0,87$ & $+0,40$ & & \\
\hline $\mathrm{MgO}$ & $+0,20$ & $-0,45$ & $+0,49$ & $-0,49$ & $\overline{-0,40}$ & $+0,17$ & $+0,36$ & $+0,15$ & \\
\hline \multirow[t]{2}{*}{ Mno } & $+0,06$ & $-0,14$ & $+0,16$ & $-0,15$ & $-0,21$ & $\overline{-0,01}$ & $\underline{0,00}$ & $\overline{-0,03}$ & $+0,15$ \\
\hline & DA & $\mathrm{H}_{2} \mathrm{O}$ & $\mathrm{SiO}_{2}$ & $\mathrm{Al}_{2} \mathrm{O}_{3}$ & $\mathrm{Fe}_{2} \mathrm{O}_{3}$ & $\mathrm{Na}_{2} \mathrm{O}$ & $\mathrm{K}_{2} \mathrm{O}$ & $\mathrm{CaO}$ & $\mathrm{MgO}$ \\
\hline
\end{tabular}

Os valores sublinhados significam correlações não significativas para uma probabilidade de 0,001 .

TABELA 7 - Parâmetros Estatísticos para a $\mathrm{SiO}_{2}, \mathrm{~K}_{2} \mathrm{O}, \mathrm{Al}_{2} \mathrm{O}_{3}$ e $\mathrm{FeO}_{3}$ nas Facies Rocha Fresca/Alterada e Bauxita

\begin{tabular}{|c|c|c|c|c|c|c|}
\hline & \multicolumn{3}{|c|}{ Rocha Fresca/Alterada } & \multicolumn{3}{|c|}{ Bauxita } \\
\hline & $\bar{x}$ & $i$ & ass. & $\bar{x}$ & $i$ & ass. \\
\hline $\mathrm{SiO}_{2}$ & 42.71 & 0.18 & -1.96 & 30.61 & 0.52 & +0.76 \\
\hline $\mathrm{K}_{2} \mathrm{O}$ & 4.39 & 0.29 & -0.99 & 0.41 & 1.18 & +1.93 \\
\hline $\mathrm{Al}_{2} \mathrm{O}_{3}$ & 33.57 & 0.18 & +0.88 & 44.01 & 0.03 & +0.067 \\
\hline $\mathrm{Fe}_{2} \mathrm{O}_{3}$ & 4.20 & 0.19 & +0.95 & 5.03 & 0.13 & -0.017 \\
\hline
\end{tabular}

TABELA 8 - Teor de Al na Goethita e Cristalinidade

\begin{tabular}{cccc}
\hline Amostra & Tipo de Material & Molar Al na Goeth & Cristalinidade* \\
\hline I 1.5 & bauxita & 25.4 & 0.52 \\
V 1.4 & bauxita & 22.3 & 0.42 \\
II 2.2 & bauxita & 22.3 & 0.40 \\
I 2.5 & bauxita & 22.3 & 0.40 \\
I 2.3 & bauxita & 23.5 & 0.45 \\
II 3.2 & bauxita & 23.5 & 0.45 \\
IV 1.3 & bauxita & 23.5 & 0.40 \\
IV 1.2 & bauxita & 23.5 & 0.42 \\
V 1.2 & bauxita & 23.5 & 0.45 \\
Média & & 23.3 & 0.43 \\
I 1.8 & material argiloso & 15.8 & 0.42 \\
V 1.8 & material argiloso & 23.5 & 0.42 \\
II 2.5 & material argiloso & 20.8 & 0.45 \\
IV 2.3 & material argiloso & 24.7 & 0.50 \\
Média & & 21.2 & 0.44 \\
\hline
\end{tabular}

* Vide Texto 
Estes valores concordam com os obtidos por FITZPATRICK \& SCHWERTMANN (1982) (goethita de bauxitas entre 20 e $25 \%$ molar de $\mathrm{AlOOH}$ e goe thita de material argiloso entre 13 e $21 \%$ molar de $\mathrm{AlOOH})$. Esta diferença é provavelmente devida ao fato de que as primeiras se formaram em ambiente de maior dis. ponibilidade de $\mathrm{Al}$ que as últimas, o que, aliás, já foi assinalado pelos autores citados e por DIDIER (1983). O grau de cristalinidade das goethitas nas bauxitas parece semelhante ao encontrado nas goethitas do material argiloso, resultado que também está de acordo com o encontrado pelos autores supra citados.

Para os poços I-2 e I-3, as descontinuidades existentes entre o nível de rocha alterada e o nível de bauxita mais ou menos argilosa devern-se ao fato de que as amostras de rocha alterada ño foram coletadas in situ no perfil, mas provém de fragmentos rolados encontrados fora do poço e representam um dos momentos do estágio inicial da alteração e não o momento imediatamente anterior representado pelas amostras de bauxita que, no desenho, aparecem sobrejacentes.

O cálculo da alumina aproveitável consta da Figura 11 como teor de $\mathrm{Al}_{2} \mathrm{O}_{3}$ na gibbsita, descontando-se a quantidade de ferro ai contida. As amostras classificadas como bauxita apre. sentam teores de $\mathrm{Al}_{2} \mathrm{O}_{3}$ aproveitável sempre maior que $42 \%$, podendo chegar até mais de $50 \%$, situaçăo em que o minério é considerado da mais alta qualidade.

\section{As fases amorfas existentes}

Com a finalidade de determinar a existênncia ou nāo de fases amorfas nos materiais estudados e avaliar sua quantidade, três amostras (rocha alterada, bauxita e argila) foram sub. metidas a ataques químicos parciais, conforme o método proposto por SEGALEN (1968). As curvas de extraçāo de amorfos mostradas nas Figuras 12,13 e 14 indicam que para cada fa. cies a quantidade $\mathrm{Fe}_{2} \mathrm{O}_{3}, \mathrm{SiO}_{2}$ e $\mathrm{Al}_{2} \mathrm{O}_{3}$ amorfos é a indicada na Tabela 9.

Parece que no início da alteraçāo a quantidade de amorfos é maior e que esse material se cristaliza à medida em que evolui, de forma que nas facies formadas unicamente por minerais secundários a presença de uma fase amorfa é pouco significativa. Assim, é lícito supor que uma fase amorfa possa ser intermediária entre a destruição dos minerais primários e a cristalizaçāo dos minerais secundários.

\section{Balanço geoquímico}

O cálculo do balanço geoquímico através do método isovolumétrico foi utilizado para todas as amostras que, ao nível macroscópico, mostrassem vestígios das estruturas originais da rocha, mesmo que as texturas, ao nível microscópico, estivessem destruídas, como no caso do material argiloso. Amostras que mostrassem sinais de compactação foram descartadas para estes cálculos.

As Tabelas 10 e 11 expressam os valores médios de densidade aparente, $\mathrm{SiO}_{2}, \mathrm{Al}_{2} \mathrm{O}_{3}$, $\mathrm{Fe}_{2} \mathrm{O}_{3}, \mathrm{Na}_{2} \mathrm{O}, \mathrm{K}_{2} \mathrm{O}$ e $\mathrm{MnO}_{2}$ em g/100 $\propto$ para amostras representativas de três estágios de alteração para as transiçōes rocha fresca-argila e rocha fresca-bauxita, respectivamente. $O$ conjunto de valores utilizados para o cálculo está plotado nas Figuras 15, 16, 17, 18, 19 e 20, onde os teores volumétricos de cada óxido aparecem em função da densidade aparente da amostra. As Tabelas 12 e 13 mostram as perdas e ganhos médios expressos em porcentagem com relação à rocha fresca.

A análise destes dados mostra que o processo de alteração laterítica das rochas alcalinas de Lages apresenta as seguintes características: $\mathrm{Mn}$;

- lixiviação gradual e progressiva de Si e

- lixiviaçao do $\mathrm{K}$ lenta no início e brutal nos estágios mais avançados;

- lixiviação brutal do $\mathrm{Na}$ no início do processo;

- aproximada conservaçăo do Al e ligeira lixiviaçāo do $\mathrm{Fe}$.

Essas características gerais sajo comuns tanto para a alteração monossialítica como para a de tendência alítica. No entanto, a intensidade do processo é mais atenuada no primeiro caso. Assim, as perdas de sillica st̃o praticamente totais para a bauxita e apenas de $2 / 3$ para o material argiloso. No caso do potássio, o comportamento das perdas é semelhante nas duas situaçסes: perda da ordem de $50 \%$ nos estágios intermediários (rocha alterada-bauxita e rocha alterada-argila) e praticamente total tanto para a argila como para a bauxita. $O$ manganès apresenta solubilidade mais baixa que a silica e o potássio nas condiçōes físico-químicas reinantes nos perfis e, portanto, perdas mais leves; nas etapas intermediárias eståo em torno de $40 \%$, mas nas bauxitas elevam-se a $64 \%$, enquanto que no material argiloso situam-se abaixo de $50 \%$. O sódio apresenta uma evolução muito especial, com perdas brutais desde o início do processo, seja na transição rocha alterada-bauxita, seja na transição rocha alterada-argila. 0 $\mathrm{Al}$ e o $\mathrm{Fe}$ são os elementos menos móveis, so- 
TABELA 9 - Avaliaçđo Quantitativa das Fases Amorfas (\% dos óxidos amorfos em relação total do óxido na amostra)

\begin{tabular}{lrrc}
\hline & $\mathrm{Al}_{2} \mathrm{O}_{3}$ & $\mathrm{SiO}_{2}$ & $\mathrm{Fe}_{2} \mathrm{O}_{3}$ \\
\hline $\mathrm{I} 2.7$ (argila) & 4.9 & 3.1 & 1.7 \\
$\mathrm{I} 2.9$ (bauxita) & 8.1 & 4.2 & 0 \\
$\mathrm{I} 2.10$ (rocha alt.) & 28.2 & 10.8 & 7.0
\end{tabular}

TABELA 10 - Valores Médios em g/100cc de cada Óxido em cada Facies de Alteração na Transição Rocha-Argila

\begin{tabular}{lcrrrrrrr}
\hline & densidade & \multicolumn{1}{c}{$\mathrm{SiO}_{2}$} & $\mathrm{Al}_{2} \mathrm{O}_{3}$ & $\mathrm{Fe}_{2} \mathrm{O}_{3}$ & $\mathrm{Na}_{2} \mathrm{O}$ & $\mathrm{K}_{2} \mathrm{O}$ & $\mathrm{MnO}_{2}$ & $\mathrm{No}$ Am. \\
\hline Arg & 1.33 & 41.7 & 57.9 & 6.3 & 0.2 & 0.6 & 0.31 & 18 \\
$\mathrm{Ra}+\mathrm{Arg}$ & 1.41 & 63.1 & 47.0 & 5.7 & 1.2 & 6.1 & 0.38 & 24 \\
$\mathrm{RF}$ & 2.49 & 124.7 & 60.5 & 8.2 & 23.2 & 12.3 & 0.59 & 6
\end{tabular}

TABELA 11 - Valores Médios em g/100cc de cada Oxido em cada Facies de Alteraçao para a Transição Rocha-Bauxita

\begin{tabular}{lcrcccccc}
\hline & densidade & $\mathrm{SiO}_{2}$ & $\mathrm{Al}_{2} \mathrm{O}_{3}$ & $\mathrm{Fe}_{2} \mathrm{O}_{3}$ & $\mathrm{Na}_{2} \mathrm{O}$ & $\mathrm{K}_{2} \mathrm{O}$ & $\mathrm{MnO}_{2}$ & No Am. \\
\hline $\mathrm{Bx}$ & 1.16 & 7.4 & 67.4 & 7.0 & 0.2 & 0.1 & 0.21 & 29 \\
$\mathrm{Ra}+$ Gibbs & 1.60 & 61.2 & 57.4 & 7.2 & 2.1 & 5.8 & 0.36 & 19 \\
$\mathrm{RF}$ & 2.49 & 124.7 & 60.5 & 8.2 & 23.2 & 12.3 & 0.59 & 6
\end{tabular}

TABELA 12 - \% de Perdas e Ganhos Médios com Relação à Rocha Fresca na Transição Rocha-Argila

\begin{tabular}{lrrrrrr}
\hline & $\mathrm{SiO}_{2}$ & $\mathrm{Al}_{2} \mathrm{O}_{3}$ & $\mathrm{Fe}_{3} \mathrm{O}_{3}$ & $\mathrm{Na}_{2} \mathrm{O}$ & $\mathrm{K}_{2} \mathrm{O}$ & $\mathrm{MnO}_{2}$ \\
\hline $\mathrm{Arg}$ & $-67 \%$ & $-4 \%$ & $-23 \%$ & $-99 \%$ & $-95 \%$ & $-47 \%$ \\
$\mathrm{Ra}+\mathrm{Arg}$ & $-49 \%$ & $-22 \%$ & $-30 \%$ & $-95 \%$ & $-50 \%$ & $-36 \%$
\end{tabular}

TABELA 13 - \% de Perdas e Ganhos Médios com Relação à Rocha Fresca na Transiçăo Rocha-Bauxita

\begin{tabular}{lcccccc}
\hline & $\mathrm{SiO}_{2}$ & $\mathrm{Al}_{2} \mathrm{O}_{3}$ & $\mathrm{Fe}_{2} \mathrm{O}_{3}$ & $\mathrm{Na}_{2} \mathrm{O}$ & $\mathrm{K}_{2} \mathrm{O}$ & $\mathrm{MnO}$ \\
\hline $\mathrm{Bx}$ & $-94 \%$ & $+11 \%$ & $-15 \%$ & $-99 \%$ & $-99 \%$ & $-64 \%$ \\
$\mathrm{Ra}+$ Gibbs & $-51 \%$ & $-5 \%$ & $-12 \%$ & $-91 \%$ & $-53 \%$ & $-40 \%$
\end{tabular}


bretudo o primeiro, cujos ganhos e perdas mé. dias expressos nas Tabelas 13 e 14 são bastante baixos. No entanto, a Figura 16 indica que existem algumas amostras que evidenciam perdas e ganhos absolutos consideráveis em A1. Quanto ao $\mathrm{Fe}$, os valores médios indicam perdas baixas e o diagrama da Figura 17 mostra que a maioria absoluta das amostras indica perdas, sendo os ganhos absolutos raros.

As tendências gerais do balanço geoquimico para os fonólitos porfiríticos de Lages sấo as mesmas evidenciadas por ALMEIDA (1977) para as alcalinas de Poços de Caldas: perda intensa de $\mathrm{SiO}_{2}, \mathrm{Na}_{2} \mathrm{O}$ e $\mathrm{K}_{2} \mathrm{O}$, conservação do $\mathrm{Al}_{2} \mathrm{O}_{3}$ e ligeira perda de $\mathrm{Fe}_{2} \mathrm{O}_{3}$.

$\mathrm{E}$ interessante notar que os elementos mais móveis, K, Si e Mn, mostram perdas maiores em média para a transição rocha alterada-bauxita do que para a transiçăo rocha alterada-argila, enquanto que os elementos menos móveis, $\mathrm{Al}$ e Fe comportam-se de maneira oposta, evidenciando maiores perdas nos níveis argilosos que nos niveis bauxíticos. Isto aparece claramente nas Figuras 15 a 20 , onde estāo projetadas as trajetórias médias dos dois tipos de transformação.

0 cálculo do balanço isovolumétrico permite estabelecer uma escala relativa de mobili. dade para os principais elementos constituintes das rochas. Do mais móvel para o mais imóvel, temos: $\mathrm{Na}, \mathrm{K}, \mathrm{Si}, \mathrm{Mn}, \mathrm{Fe}$ e Al. Os dois primeiros estão ausentes tanto das argilas como das bauxitas. O Si está praticamente ausente das bauxitas e presente em $1 / 3$ de sua quantidade inicial nas argilas. $\mathrm{O} \mathrm{Mn}$ está presente nas duas facies, mas apresenta-se mais concentrado nas argilas. $\mathrm{O} F e$ e o $\mathrm{Al}$ constituem o resíduo da alteração e permanecem mais ou menos em sua quantidade inicial mesmo nos horizontes mais alterados.

O comportamento dos elementos que acaba de ser descrito é a outra face do fenômeno já caracterizado ao nível mineralógico. Assim, no início da alteraçao, o primeiro mineral que se desestabiliza é a nefelina, com lixiviação principalmente da silica e do sódio e precipitação do alumínio. Mais ou menos concomitantemente, a egirina libera em solução esses mesmos elementos e o ferro que reprecipita como goethita, talvez pelo intermediário de uma fase amorfa. Segue-se finalmente a alteração do feldspato alcalino, com precipitação do Al como gibbsita. No caso de a alteraçáo seguir pelo caminho da monossialitização, a lixiviaçđóo da sflica é incompleta e, no lugar da gibbsita, precipita a halloisita.

\section{Gênese da Jazida}

A jazida de bauxita do distrito de Lages originou-se por laterização intensa dos fonólitos porfiríticos da Serra da Farinha Seca, em sítios topográficos que satisfizessem duas condiçøes.

- drenagem desimpedida, permitindo completa lixiviação da silica e das bases:

- declive moderado, permitindo que o aprofundamento dos perfis de alteraçฐ̃o prevalecesse sobre a erosáo do material alterado.

Estes sítios correspondem aos altos do relevo; nas encostas é possível encontrar um discreto nível de bauxita coluvionar e, nas baixadas, o minério está completamente ausente.

O minério originou-se por bauxitização direta, isto é, os minerais primários, feldspato alcalino e nefelina, alteraram-se diretamente em gibbsita. Isto pôde ser amplamente verificado por evidências micromorfologicas: a bauxita apresenta-se estruturada como réplica da textura dos fonólitos porfiríticos, onde a gibbsita substitui pseudomorficamente os silicatos félsi$\cos$ e a goethita, o mineral ferromagnesiano. A bauxita encontra-se muitas vezes cortada por veios de gibbsita pura, bem cristalizada, originada de soluç̧es que se enriqueceram de alumínio por dissolução da gibbsita de níveis superiores do perfil, em condiçōes de $\mathrm{pH}$ mais ácidos.

Os niveis argilosos intercalados na bauxita derivam, em parte, de um episódio de laterizaçđo menos intensa, quando os silicatos primários alteraram-se em halloisita e, em parte, da ressilicificaçăo da gibbsita originada de um episódio de laterização mais intensa. $\mathrm{A}$ fonte de sílica para a ressilicitação poderia ser encontrada nos sedimentos que cobriam as rochas alcalinas, hoje erodidos, ou em fragmentos remanescentes de fonólitos nos níveis bauxíticos superiores.

As jazidas de bauxita de Poços de Caldas (ALMEIDA, 1977) e do Arkansas (GORDON et al., 1958) apresentam algumas feiçбes semethantes às do depósito de Lages. Desenvolvidas sobre rochas alcalinas, mostram, às vezes, niveis argilosos na base do perfil da alteraçđo ou intercalados com a bauxita de estrutura conservada.

TABELA 14 - \% de Amorfos sobre o Total Extraído

$\begin{array}{lccc}\text { Amostra } & \mathrm{SiO}_{2} & \mathrm{Al}_{2} \mathrm{O}_{3} & \mathrm{Fe}_{2} \mathrm{O}_{3} \\ \text { LG-10 } & 39.5 & 58.6 & 94.9\end{array}$


No caso de Poços de Caldas, ALMEIDA (1977) acredita que a alteraçđo argilosa seja posterior à alteraçáo bauxítica e que tenha se dado por diminuiç̧̃o da eficiência da drenagem à medida que o relevo ta sendo aplainado. MELFI \& CARVALHO (1983) também crẻem que a caolinização é o processo ativo atualmente em Poços de Caldas, sendo a bauxitização correspondente a uma evolução passada, a não ser em setores restritos de encostas abruptas. MONIZ et al. (1972) consideram que os niveis de caolinita intercalados no minério de Poços de $\mathrm{Cal}$ das são derivados de ressilicificação da gibbsita. No Arkansas, GORDON et al. (1958) sustentam a idéia de que os niveis argilosos formam-se por alteração da rocha fresca abaixo do nível bauxítico, em decorrência da elevação do nível d'água que acompanhou a deposição dos sedimentos eocênicos. Admitem também a ressilicificação da gibbsita como processo gerador dos niveis argilosos.

As características da bauxita do distrito de Lages sto as seguintes:

- dados físicos: bauxita de estruturaconservada, cor amarela, porosa, com densidade variando de 0,9 a 1,6 ;

- composiçđ̃o química média: $\mathrm{Al}_{2} \mathrm{O}_{3}$ $58 \%, \mathrm{SiO}_{2} 6 \%$ e $\mathrm{Fe}_{2} \mathrm{O}_{3} 6 \%$;

- composição mineralógica: essencialmente gibbsita e goethita, além de traços de boehmita, hematita, zircđ̃o e anatásio;

- reservas: 5,8 milhōes de toneladas, distribuidas em uma área de aproximadamente 1 $\mathrm{km}^{2}$, com espessura variando entre 0,5 e $6 \mathrm{~m}$ (SZUBERT \& VERGARA, 1975).

A qualidade do minério do distrito de $\mathrm{La}$ ges é excelente, apresentando teores de $\mathrm{Al}_{2} \mathrm{O}_{3}$ semelhantes aos de Poços de Caldas, teores de $\mathrm{SiO}_{2}$ um pouco mais elevados (Poços $4 \%$ ) e teores de $\mathrm{Fe}_{2} \mathrm{O}_{3}$ mais baixos (Poços 9\%). Em termos de reservas, os 5,8 milhőes de toneladas (superestimados, pois calculados para uma densidade do minério de 2,5 ) representam muito pouco no panorama brasileiro (reservas de mais de 4 bilhōes de toneladas), mas podem ser im. portantes localmente, dada a inexistência de outras fontes de alumínio no sul do Brasil. Por outro lado, as reservas poderiam ser aumentadas se o limiar para silica fosse admitido a níveis superiores, isto é, se o material mais argiloso pudesse ser incluido, desde que este material sofresse lavagem prévia, como processo concentrador de gibbsita. Estudos da composição mineralógica das várias fraçōes granulométricas revelaram que nos materiais compostos de gibbsita e halloisita ou caolinita, as fases argilosas estão sempre concentradas na fração $<0,062 \mathrm{~mm}$.

\section{ALTERAÇÃO DE OUTROS TIPOS DE ROCHAS}

Outros tipos de rochas, além dos fonólitos porfiríticos da Serra da Farinha Seca seriam potencialmente capazes de produzir, por alteraçđo, bauxita. Os resultados da investigação sobre a constituição, mineralógica e química das facies alteradas sobre estas rochas sశo descritos a seguir

\section{Fonólitos do Morro do Tributo e da Chapada}

A meteorização dos fonólitos for estudada por meio de amostras provenientes de perfis de alteraçđo aflorantes em cortes de estrada e de amostras de córtex de alteração de fragmentos de rocha fresca.

No plano mineralógico, os produtos de alteração dos fonólitos consistem sempre numa mistura de minerais primários e de halloisita, sendo largamente dominantes os primeiros. As vezes aparecem nos difratogramas discretos $\mathrm{pi}$ $\cos$ a aproximadamente $15 \mathrm{~A}$, o que revelaria a presença de traços de esmectita, cuja natureza ño foi investigada. No Morro do Tributo, a rocha alterada encontra-se cortada por veios de material branco de aspecto porcelânico que a análise por difração de raios $\mathrm{X}$ revelou ser halloita pura, como já havia sido observado por LIN. DSTAED (1972). MONIZ et al. (1972) mencionam a existência de veios de halloisita porcelânica em Poços de Caldas e atribuem sua origem à precipitação a partir de soluçōes ricas em silício e aluminio.

Ao microscópio, os fonólitos alterados mostram substituiç̧̃o pseudomórfica do feldspato alcalino e da nefelina por material argiloso e um início de ferruginização da egirina. Em niveis mais evoluidos do perfil, a estrutura da rocha desaparece e é substitufda por uma massa argilosa mais ou menos amarelada, composta de feldspato e halloisita. As amostras do córtex de fragmentos de fonólitos frescos nฮ̄o evidenciaram aos raios $\mathrm{X}$ a presença de minerais secundários, embora constituam-se em material branco e pulverulento, portanto bem alterado. Trata-se, na verdade, de uma mistura de minerais primários e compostos amorfos de silício e aluminio. O teor de amorfos sobre o total extraido, calculado a partir da Figura 21. está expresso na Tabela 14 
Em resumo, os fonólitos alteram-se de maneira incipiente, isto $\hat{e}$, mesmo nos horizontes mais evoluídos os minerais primários predominam. $\mathrm{O}$ principal mineral secundário é a halloisita, originada, talvez, pelo intermediário de uma fase amorfa. Não foi constatada a neoformação de gibbsita, senåo como iraço em algumas poucas amostras.

A Tabela 15 mostra a composição química de 6 exemplares de fonólitos. Do ponto de vista químico, essas rochas se assemelham muito aos fonólitos porfiríticos, apresentando apenas ligeiras diferenças, quais sejam:

- são ligeiramente mais ácidas;

- apresentam teores de $\mathrm{Fe}_{2} \mathrm{O}_{3}$ e $\mathrm{CaO}$ mais baixos;

- apresentam teores em $\mathrm{K}_{2} \mathrm{O}$ e $\mathrm{Na}_{2} \mathrm{O}$ um pouco mais altos;

- mostram menor grau de hidratação.

A composição química dos produtos de alteraçāo dos fonólitos é mostrada na Tabela 16 , onde são distinguidos 3 estágios de graus de alteração crescentes. A tendência geral é a mesma verificada para os fonólitos porfiríticos, isto é, perda progressiva de silica e bases (retardamento da perda de $\mathrm{K}_{2} \mathrm{O}$ em relaçāo ao $\mathrm{Na}_{2} \mathrm{O}$ ) e aumento de $\mathrm{Al}_{2} \mathrm{O}_{3}$, $\mathrm{TiO}_{2}$ e $\mathrm{H}_{2} \mathrm{O}^{+} . \mathrm{O} \mathrm{MgO}$ apresenta comportamento aparentemente anômalo, aumentando nas facies mais alteradas em relaça à rocha fresca. Isto pode ser devido a erros analíticos, pois este elemento foi dosado numa faixa de teores para a qual a absorção atômica não fornece boa exatidão. Quanto ao ferro, parece que, de fato, ele é perdido na alteraçăo, o que já era suspeitado a partir da observação de campo da cor muito clara, praticamente bran$\mathrm{ca}$, dos niveis alterados sobre fonólitos. A explicação clássica para a remoçāo do ferro, concomitante com a retençâo do alumínio, repousa na questão da variação do potencial de óxidoreduçāo e do $\mathrm{pH}$ do meio (NORTON, 1973). Assim, pequenas variaçōes de Eh e de $\mathrm{pH}$ seriam responsáveis pela acumulaçấo preferencial do alumínio sobre o ferro. Com relação ao caso específico de Lages, contudo, a autora não dispōe de argumento para caracterizar o ambiente gerador das alteritas nos termos dos parâmetros acima mencionados.

A alteração dos fonólitos fica, portanto, caracterizada como de tendência laterítica pouco pronunciada: os perfis ș̄o pouco espessos, os niveis de alteração contém grande porcentagem de minerais primários e o principal mineral secundário presente, a halloisita, resulta de uma

TABELA 15 - Composição Química dos Fonólitos (\% em peso dos 6xidos)

\begin{tabular}{|c|c|c|c|c|c|c|c|}
\hline & LG-03 & $L G \cdot 10$ & $L G-63$ & $I N-1$ & $M T-2$ & 1006 & Media \\
\hline $\mathrm{SiO}_{2}$ & 55.18 & 55.64 & 57.00 & 49.82 & 55.91 & 55.84 & 54.90 \\
\hline $\mathrm{TiO}_{2}$ & 0.18 & 0.10 & 0.27 & 0 & 0 & 0.02 & 0.10 \\
\hline $\mathrm{Al}_{2} \mathrm{O}_{3}$ & 23.24 & 23.70 & 21.07 & 23.75 & 23.67 & 21.27 & 22.78 \\
\hline $\mathrm{Fe}_{2} \mathrm{O}_{3}{ }^{*}$ & 2.24 & 2.24 & 1.77 & 2.43 & 1.94 & 2.20 & 2.14 \\
\hline MnO & 0.16 & 0.15 & 0.21 & 0.06 & 0.35 & 0.20 & 0.19 \\
\hline $\mathrm{MgO}$ & 0.11 & 0.05 & 0.05 & n.d. & 0 & 0.19 & 0.08 \\
\hline $\mathrm{CaO}$ & 1.08 & 0.99 & 0.43 & 1.39 & 0.65 & 1.08 & 0.94 \\
\hline $\mathrm{K}_{2} \mathrm{O}$ & 5.57 & 5.85 & 5.60 & 7.88 & 5.25 & 6.83 & 6.16 \\
\hline $\mathrm{Na}_{2} \mathrm{O}$ & 9.57 & 9.67 & 9.67 & 11.68 & 11.01 & 9.93 & 10.25 \\
\hline $\mathrm{H}_{2} \mathrm{O}^{*}$ & 2.15 & 1.99 & 1.18 & 1.62 & 1.51 & 1.53 & 1.67 \\
\hline $\begin{array}{l}\text { Densidade } \\
\text { Aparente }\end{array}$ & 2.39 & 2.60 & 2.54 & n.d. & n.d. & n.d. & 2.57 \\
\hline
\end{tabular}

LG-03 - Fonólito da Chapada (Lab. Geoquímica IGUSP)

LG-10 - Fonólito da Chapada (Lab. Geoquimica IGUSP)

LG-63 - Fonólito do Tributo (Lab, Geoquímica IGUSP)

IN-1 - Serra da Chapada (citado por LINDSTAED, 1972)

MT-2 - Serra do Cadeado (citado por LINDSTAED, 1972)

1006 - Morro do Tributo (citado por LINDSTAED, 1972)

- Fe total calculado como $\mathrm{Fe}_{2} \mathrm{O}_{3}$ 
dessilicificaçăo incompleta dos feldspatos e da nefelina.

\section{Micronefelina-sienitos do Cerro Alto}

O corpo alcalino do Cerro Alto, além dos fonólitos porfiríticos da Serra da Farinha Seca, foi investigado pela CPRM (SZUBERT \& VERGARA, 1975) para bauxita. A pesquisa demonstrou que o material alterado era muito pobre em alumina e rico em silica, de modo que não podia ser classificado sequer como argilo-bauxitico. LINDSTAED (1972) mostrou que a alteração de uma amostra de Cerro Alto era de caráter incipiente.

Algumas amostras de córtex de alteraçđ̃o de fragmentos de micronefelina-sienito foram analisadas por difração de raios-X pela autora deste trabalho. Os resultados indicaram uma mistura de minerais primários e gibbsita, o que leva a supor que estas rochas possam apresentar tendência à alitizaçẫo, porém de intensidade muito reduzida, ou que os niveis mais profundamente alterados foram erodidos.

\section{Analcita-Traquitos}

Num dos pequenos corpos de analcita-traquito situado a sul da Serra do Cadeado (Fig. 1) foram amostrados 3 níveis de alteração provenientes de um fragmento de rocha com exfoliaçāo esferoidal. A amostra de rocha fresca revelou aos raios-X ser constituida essencialmente por feldspato alcalino e analcita. Nos dois níveis mais alterados só aparece o feldspato alcalino, indicando que a analcita se altera desde bem cedo. Dada a ausência de minerais secundários em material de aspecto bem alterado (branco e pulverulento), supoe-se que aqui, a exemplo do que ocorre com os fonólitos, os primeiros estágios da alteraçăo sejam representados por material amorfo.

\section{Fonólitos Porfiríticos do Licurgo}

Um pequeno corpo de fonólito porfirí. tico que ocorre no limite ocidental do maciço mostra niveis alterados semelhantes aos dos corpos da Serra da Farinha Seca. Amostras provenientes de um poço executado para pesquisa de minério indicaram a presença de níveis argilosos e de níveis bauxíticos.

\section{Diabásios da Serra da Farinha Seca}

Corpos de diabásio encontram-se associados aos fonólitos porfiríticos da Serra da Farinha Seca, ocupando posiçōes de altos topográficos, em Barra dos Indios e na Colonia Faxinal (Fig. 1). A alteração destas rochas é de mesma tendência que a das alcalinas associadas, isto é, apresenta caráter de alitização. A rocha fresca, composta essencialmente por plagioclásio e augita, transforma-se em material constituido por gibbsita e goethita. A Tabela 17 mostra a com-

TABELA 16 - Composição Química (\% peso) dos Produtos de Alteraçāo dos Fonólitos

\begin{tabular}{lrrr}
\hline & Estagio 1 & Estagio 2 & Estdgio 3 \\
\hline $\mathrm{SiO}_{2}$ & 55.89 & 52.78 & 50.60 \\
$\mathrm{TiO}_{2}$ & 0.24 & 0.18 & 0.40 \\
$\mathrm{Al}_{2} \mathrm{O}_{3}$ & 24.56 & 29.16 & 33.35 \\
$\mathrm{Fe}_{2} \mathrm{O}_{3}^{*}$ & 1.65 & 1.89 & 1.95 \\
$\mathrm{MnO}$ & 0.07 & 0.06 & 0.12 \\
$\mathrm{MgO}$ & 0.87 & 0.62 & 0.10 \\
$\mathrm{CaO}$ & 0.98 & 0.51 & 0.09 \\
$\mathrm{~K}_{2} \mathrm{O}$ & 5.42 & 5.40 & 2.17 \\
$\mathrm{Na}_{2} \mathrm{O}$ & 2.68 & 0.76 & 0.55 \\
$\mathrm{H}_{2} \mathrm{O}^{*}$ & 6.35 & 9.39 & 12.18 \\
Densidade & 2.20 & 1.66 & 1.22 \\
$\mathrm{Aparente}$ & 2 & 3 & 1 \\
No de Amostras & 2 & & \\
\hline
\end{tabular}

Estágio 1 - Rocha pouco alterada (Lab. Geoquímica IGUSP)

Estágio 2 - Rocha alterada (Lab. Geoquimica IGUSP)

Estágio 3 - Rocha bem alterada (Lab. Geoquímica IGUSP)

- $\quad \mathrm{Fe}$ total calculado como $\mathrm{Fe}_{2} \mathrm{O}_{3}$ 
posição quimica da rocha fresca e de seu produto de alteraçato, ambos provenientes de um fragmento apresentando exfoliação esferoidal. Aqui também o processo caracteriza-se por perda de sílica e bases e por concentração de alumínio e ferro, dando como produto uma bauxita ferruginosa. A CPRM considerou este material, pelo seu alto teor em ferro, destituido de interesse econômico (SZUBERT \& VERGARA, 1975).

\section{Folhelhos do Grupo Passa Dois}

Um afloramento de folhelho, situado a sul do corpo de fonólito da Serra da Chapada foi mostrado com a finalidade de comparar a tendência de alteraçăo destas rochas com a das alcalinas.

O folhelho fresco é constituido essencialmente por quartzo e illita $e$, secundariamente por caolinita. Com a alteração, a única transformaçđ̃o que ocorre é a passagem da illita para caolinita; este mineral parece estável no ambien. te supérgeno.

\section{CONSIDERAÇŌES FINAIS}

A bauxitizaçăo é essencialmente um processo de dissolução e lixiviaçđo da sílica e das bases dos silicatos primários formadores da rocha-mãe e concomitante enriquecimento em alumínio, cristalizado principalmente sob forma de gibbsita. Para que a bauxitização possa ocorrer, é necessária toda uma conjuntura de fatores favoráveis composiçāo mineralógica e química adequada da rocha-māe, condiçð̄es climáticas suficientemente agressivas para a desestabilização dos minerais primários, condiçōes de drena gem dos perfis que permitam a evacuaçăo da silica e, finalmente, condiçōes de preservaçăo dos perfis de alteração dos processos erosivos. Todos estes fatores precisam atuar tempo suficiente para que os perfis desenvolvam espessuras de minério que possam ser consideradas interessan. tes.

Serão discutidos a seguir cada um destes fatores e seu papel na gênese da bauxita do distrito de Lages.

\section{Influência da Rocha-mãe}

Em Lages, a bauxita deriva principalmente do fonólito porfirítico. $\hat{\mathrm{E}}$ uma rocha extremamente favorável para gerar bauxita pois possui teor elevado de $\mathrm{Al}_{2} \mathrm{O}_{3}$ e uma relaçāo $\mathrm{SiO}_{2} / \mathrm{Al}_{2} \mathrm{O}_{3}$ baixa. Seus constituintes mineralógicos, o feldspato alcalino e a nefelina, são minerais que se alteram facilmente. $\mathrm{A}$ ausência de quartzo nestas rochas é outro fator extremamente favorável, pois a lenta disoluçāo deste mineral eleva o teor de $\mathrm{H}_{4} \mathrm{SiO}_{4}$ nas águas, dificultando a cristalizaçāo da gibbsita.

O micronefelina-sienito também parece ser uma rocha capaz de gerar bauxita. O relatório da CPRM (SZUBERT \& VERGARA, 1975) informa que parte dos corpos alcalinos bauxitizados da Serra da Farinha Seca são constituídos por esta variedade litológica. Por outro lado, a autora deste trabalho constatou que em

TABELA 17 - Composição Química do Diabásio e de seu Produto de Alteração

\begin{tabular}{lrr}
\hline & Diábdsio $^{* *}$ & Diabaisio Alt.** \\
\hline $\mathrm{SiO}_{2}$ & 50.00 & 12.42 \\
$\mathrm{TiO}_{2}$ & 1.40 & 0.15 \\
$\mathrm{Al}_{2} \mathrm{O}_{3}$ & 14.74 & 33.54 \\
$\mathrm{Fe}_{2} \mathrm{O}_{3}{ }^{*}$ & 13.59 & 31.46 \\
$\mathrm{MnO}$ & 0.22 & 0.08 \\
$\mathrm{MgO}$ & 1.14 & 0.08 \\
$\mathrm{CaO}$ & 15.39 & 0.39 \\
$\mathrm{~K}_{2} \mathrm{O}$ & 0.87 & 0.20 \\
$\mathrm{Na}_{2} \mathrm{O}$ & 2.59 & 0.23 \\
$\mathrm{H}_{2} \mathrm{O}^{*}$ & 1.13 & 20.75 \\
Densidade & & 1.49 \\
Aparente & 2.87 & \\
\hline
\end{tabular}

* Fe total calculado como $\mathrm{Fe}_{2} \mathrm{O}_{3}$

** Análises realizadas no Lab. Geoquímica IGUSP 
Cerro Alto, apesar de não haver bauxita, a tendência da alteração é em direçđo à alitizaçăo.

Os fonólitos, no entanto, parecem nāo ser rochas capazes de gerar bauxita. As evidências disponiveis indicam que estas rochas al teram-se para material halloisítico, através do intermediário de uma fase amorfa importante. A razão para a diferença de comportamento frente à alteração entre as três principais variedades de rochas alcalinas do distrito de Lages deve ser atribuída menos a diferenças em suas composiçōes químicas e mineralógicas, mas a particularidades texturais e ao grau de fraturamento. Em Poços de Caldas, ALMEIDA (1977) constatou que os tinguaítos e os fonólitos são rochas mais fraturadas que os nefelina-sienitos e, em função disto, são mais facilmente transformadas em bauxita. Em Lages, esta questão não foi suficientemente esclarecida.

Os diabásios associados às alcalinas da Serra da Farinha Seca, embora apresentem tendência à completa alitizaçăo, não geram bauxita, em função de sua composição química desfavorável. Enquanto as rochas alcalinas apresentam uma razāo $\mathrm{SiO}_{2} / \mathrm{Al}_{2} \mathrm{O}_{3}$ igual a 2,3 , nos basaltos esta razão sobe a 3,4 . Mas, mais importante que a relativa pobreza em $\mathrm{Al}_{2} \mathrm{O}_{3}$ é a baj. xa razảo $\mathrm{Al}_{2} \mathrm{O}_{3} / \mathrm{Fe}_{2} \mathrm{O}_{3}$ nos diabásios $(1,1)$ em comparação com as alcalinas $(7,2)$; o elevado teor em ferro nas rochas básicas impede a formação de bauxita de boa qualidade.

Os sedimentos gondwånicos aflorantes no domo de Lages também não produzem bauxita. Geralmente têm em sua constituição bastante quartzo, que é um mineral de baixissima suscetibilidade à alteração. A caolinita, outro componente importante, mostrou-se estável nas condiçð̄es de alteração reinantes em Lages. Este é, aliás, um outro argumento favorável à idéia de que a bauxitizaçāo foi direta, ño tendo se dado por intermediário de uma fase caolinítica ou halloisítica.

\section{Influência do Clima}

A maior parte dos autores concorda que é preciso de um clima úmido e quente para a formação de bauxita laterítica. Segundo BARDOSSY (1983) as condições climáticas ideais seriam caracterizadas por temperaturas médias anuais entre 20 e $26^{\circ} \mathrm{C}$ e precipitaçāo superior a $1200 \mathrm{~mm}$ anuais, com pelo menos 1 ou $2 \mathrm{me}$ ses secos. Em Lages, apesar de haver disponibilidade de água suficiente, a temperatura média de $15^{\circ} \mathrm{C}$ é um pouco baixa. $\mathrm{O}$ efeito da baixa temperatura consiste em aumentar a viscosidade da água, do que decorre uma percolação mais lenta e consequente lixiviaçāo incompleta de $\mathrm{SiO}_{2}$. Assim, sob climas subtropicais, a tendência da alteração seria em direçāo da monossialitização, com formação de caolinita, ou halloisita.

Em Lages, a fase de bauxitizaçato deve ter ocorrido num periodo de clima um pouco mais quente que $\mathrm{o}$ atual, quando o balanço global da radiaç̃o solar era mais favorável. BARDOSSY (1981) admite que este parâmetro vem decrescendo paulatinamente em escala mundial desde o Eoceno.

Lages representa no território brasileiro um limite latidudinal, além do qual mais nenhuma outra jazida laterítica é encontrada.

\section{Influência do Relevo}

As bauxitas de Lages situam-se nas cristas de um platô ondulado, a altitudes entre 900 e $950 \mathrm{~m}$, desniveladas de 50 a $100 \mathrm{~m}$ em relação ao nível de base local (a várzea do rio dos Indios que corta o platô está a $850 \mathrm{~m}$ ). Esta posiçăo topográfica é muito favorável à gênese de bauxita, pois assegura uma drenagem desimpedida, fator condicionante da eliminação da silica. Como foi visto no ítem III.2, nas encostas e nas baixadas, a tendência da alteraçăo é para a formaçăo de argilas.

A maior parte das reservas de bauxita laterítica do mundo ocorrem a altitudes entre 300 e $1000 \mathrm{~m}$, com elevaçōes relativas de 50 a $200 \mathrm{~m}$ (BARDOSSY, 1983) tal como acontece em Lages.

\section{Época e Duração da Bauxitização}

A idade de 65 milhōes de anos para as rochas alcalinas de Lages coloca um limite inferior para o início do processo de bauxitização. Aliás, este limite deve ser posterior a 65 m.a. porque é preciso considerar o tempo que estas rochas levaram para serem expostas à superficie. A datação exata do processo de bauxitizaçāo nẫo pôde se determinada porque as bauxitas de Lages năo estāo claramente associadas a nenhuma superfície de aplainamento passível de ter sua idade conhecida.

Dadas as limitaçōes expostas acima, e considerando o que foi discutido no item referente as condicoes climáticas, pode-se dizer apenas que a bauxitizaçāo deve ter se dado, principalmente, no Terciário, tendo diminuído sua intensidade em tempos mais recentes. 


\section{AGRADECIMENTOS}

$\mathrm{O}$ acesso à área e a visita aos depósitos de bauxita foram enormemente facilitados pelo Prof, L.F. Scheibe, profundo conhecedor da geologia da regiao, a quem consigno meus maiores agradecimentos. O Prof. Dr. A.J. Melfi e o Prof. Dr. C.B. Gomes contribuíram para o fi- nanciamento dos trabalhos de campo. O Prof. Dr. M.L. Formoso e o Prof. A.J. Melfi acompanharam parte das visitas a área. $O$ estudante M. Blumer, bolsita de iniciaçđo científica da FAPESP, colaborou na execuçđo dos trabalhos de laboratório. O CNPq concedeu ajuda financeira aos trabalhos de campo e de laboratório. A todas essas pessoas e entidades, meu sincero reconhecimento.

\section{REFERÊNCIAS BIBLIOGRÁFICAS}

AHRENS, L.H. (1966) Element distributions in specific igneous rocks. VIII. Geoch. Cosm. Acta 30: 109-122.

ALMEIDA, E.B. (1977) Geology of the bauxites deposits of the Poços de Caldas District, State of Minas Gerais PHD. Thesis, Un, Stanford, 273 p.

ALONSO, M.T.A. (1977) Vegetaçoo do regifo sul do Brasil. Geogr. do Brasil - regifo sul, 5: $81-109$

AMARAL, G.; BUSHEE, J.; CORDANI, U.G.; KAWASHITA, K.; REYNOLDS, J.H. (1967) Potassilum-angon dates of alkaline rocks from sotuthern Brasil. Geoch. Cosm. Acta 31:117-142.

BARBOSA, O. (1933) Enuprivas de Lages, Santa Catarina. Bol. Serv. Geol. Min. do Min. Agr., 69:15-18.

BARDOSSY, G. (1981) Palaeoenvironments of laterites and lateritic bauxites - Effect of global tectonism on bauxite formation. Proc. I Int. Sem. Lat. Proc.. India: 287-301.

BARBOSSY, G. (1983) A comparison of the main lateritic bauxitic region of our globe. Proc. II Int. Sem. Lat. Proc., Såo Paulo: $15-51$.

CHESWORTH, W. (1972) The stability of gibbsite and boehmite at the surface of the earth. Clays and Clay Min. $20: 369-374$.

DELVIGNE, J. (1965) Pédogenèse en zone tropicale. La formation des minéraux secondaires en milleu ferraittique. Mem. ORSTOM, 13, Dunod, Paris, 177 p.

DIDIER, P. (1983) Paragenèses d oxydes et hydroxydes de fer dans les bauxites et les cuirasses fermuginenses. Th. Un, Poitiers, $150 \mathrm{p}$.

FITZPATRICK, R.W. \& SCHWERTMANN, U. (1982) Al-substizuted goe thite an indicator of pedogenic and other weathering environments in South Africa, Geoderma, 27:335-347.

FUJIMORI, S. (1975) Haloisita no embasamento cristalino alterado de Saluador (BA). Rev. Bras. Geoc. 5(4): 269-273.

GOLDMAN, M.I. \& TRACEY JR., J.I. (1946) Relations of bauxite and kaolin in the Arkansas bauxite deposits. Ec. Geol. XLI(6): 567-575.

GORDON, M.; TRACEY J.I.; ALLIS, M.W. (1958) Geology of the Arkansas bauxite region. Geol. S. Prof. Pap. 299: 1-268.

GUAZELL1, W. \& FEUO, F.L. (1970) Mapa geológico de semi-detalhe do centro-leste e sudoeste de Santa Cata rina. Petrobrás, Desul, Rel. 396, anexo 14, Ponta Grossa (inédito).

JOST, H. (1967) The dome-folded structure of Lages, Santa Catarina Southern Brazil. 1 Inst. Symp. Gondw. Strat, and Pal. Guidebook exc, no 3:67-72.

KIMPE, C.; GASTUCHE, M.C.; BRINDLEY, G. W. (1964) Low temperature synthesis of kaolin minerals. Am. Min. 49:1-16.

LEPREVOST, A. (1971) A bauxita da fazenda Tributo, Lages-SC. Bol. Und. Fed. Paraná, 29:1-22.

LINDSTAED, H.P. (1972) A alteraçđo das rochas alcalinas, Lages. Santa Catarina. Diss. Mestrado UFRS, Porto Alegre, 54 p. (inédito).

LOCZY, L. (1968) Basic and alkalic volcanics of the State of Santa Catarina, Bnazil. An. Ac. Br. Cienc., 40: $187-193$.

MACKENZIE, R.C. (1957) The differential thermal investigation of clays. Min. Soc. London, 456 p.

MELFI, A.J. \& CARVALHO, A. (1983) Bauxitization of alkaline rocks in Southern Brazil. Inst. Coll. CNRS. Petrology of weathering and soils (inédito).

MILLOT, G. \& BONIFAS, M. (1955) Transformation isonolumetrique dans les phenomenes de laterisation et de bauxitization. Bull. Serv, Cart, Geol. Als. Lor. 8(1); 3-20.

MONIZ, A.C. (1969) Estudo minerológico de argilas do maciço alcalino de Poços de Caldas. Bol. Fac. Fil. Ciênc. Letr. USP, 304:1-134. 
MONIZ, A.C; WILLIAM, D.D.; SANTOS, P.S.; SANTOS, H.S. (1972) Clay minerals in veins associated wi. bauxites of Poços de Caldas, MG. An, XXVI Congr. Bras, Geol., Belem, 1:221-230.

NORTON, S.A. (1973) Laterite and bauxite formarion. Ec. Geol., 68: 353-361.

OLIVEIRA, S, M. B. (1978) Alteraçōo de nochas ultrabdsicas: tratamento estatistico preliminar de dados quimicos. Res, XXX Congr, SBPC, Sđo Paulo: 391 p.

ROSS, G. I, KODAMA, H.; WANG, G.; GRAY, J. T.; LAFRENIÊRE. L. B. (1985) Halloysite from a strongly weathered soll at Mont Jacques Cartier, Quebec. Soil Sc. Soc. Am. I. 47:327-332.

SCHEIBE, L.F. (1979) Estudo petrolbgico e geoquimico dos carbonatitos da Fazenda Varela, Lages, SC., Brasih. Diss. Mestrado UFRS, Porto Alegre, 120 p. (inédito).

SCHEIBE, L.F. \& FORMOSO, M.L. (1982) Contribuiço da geoquímica das terras raras de caracterizeçóo dos carbonatitos da Fazenda Varela, Lages, SC. Rev, Bras. Geoc., 12:553-561.

SCHEIBE, L.F.; GOMES, C. B.; COUTINHO, J.M. V. (1984) Caracterizaçāo petrográfica das nochas alcalinas de Lages, SC. An. XXXIII Congr. Bras, Geol., Rio de Janeiro, IX: $4377-4391$.

SCHELLMANN. W. (1981) Considerarions on the definition and classification of laterites. Proc. I Int. Sem. Lat. Proc,, India: 1-10

SEGALEN, P. (1968) Note sur une methode de détermination des produits minéraux amorphes dans certains sols d hydroxydes tropicaux. Cah ORSTOM, sér. Péd. 6(1): 105-126.

SZUBERT, E.C. \& VERGARA, V.D. (1975) Avaliaçđo das reservas e da qualidade dos depósitos de bauxita do municipio de Lages, SC. Rel. CPRM, ag. Porto Alegre, 68 p. linéditol. 


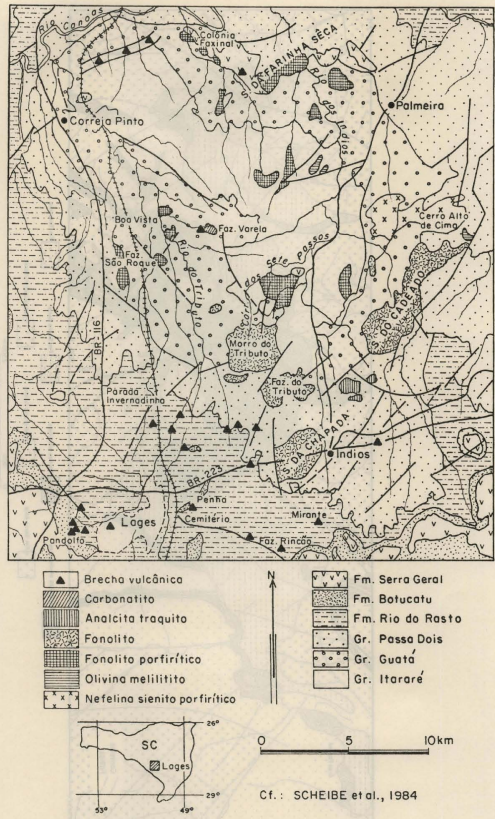

Figura 1 - Rochas alcalinas de Lages, SC 


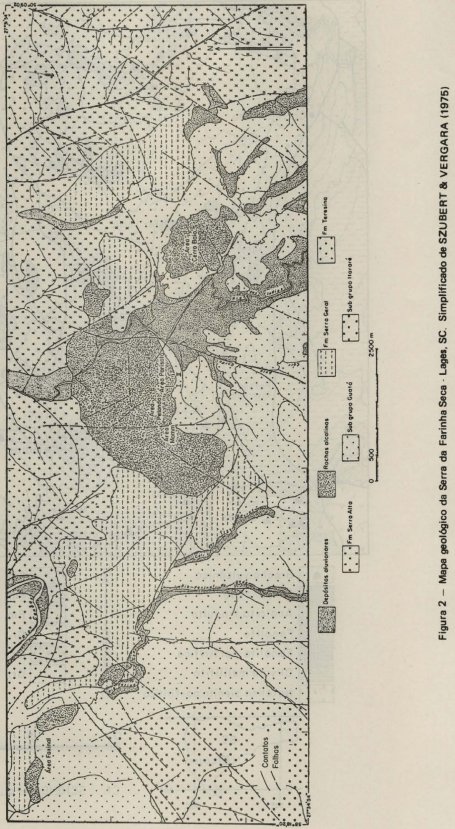




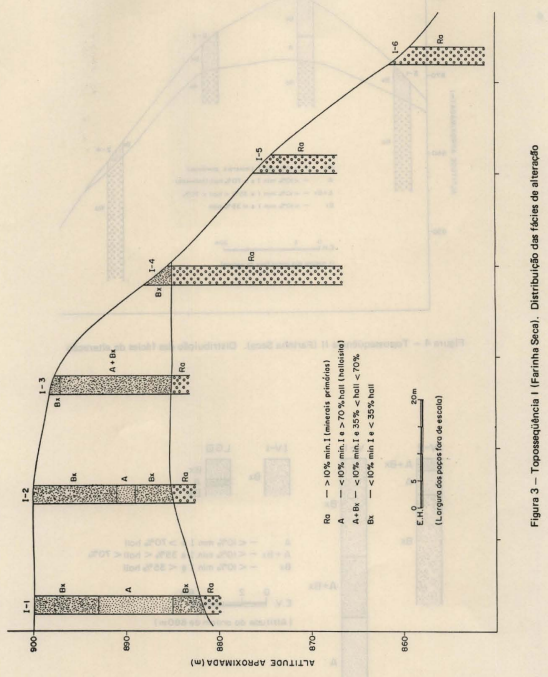




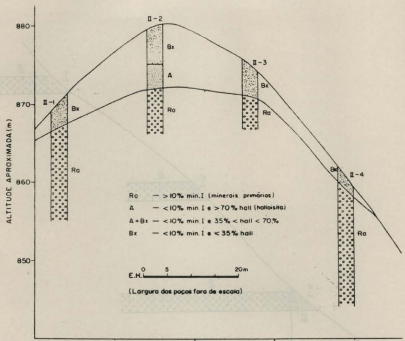

Figura 4 - Topossequeência II (Farinha Seca). Distribuição das fácies de alteracăo
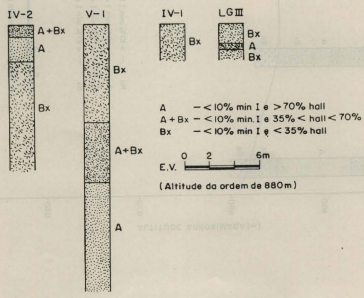

Figura 5 - Jazida Pelanda. Pocos (IV-2 e V-1) e perfis na frente de lavra (IV-1 e LGIII) 


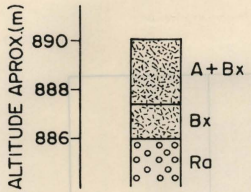

$$
\begin{aligned}
& A+B x-<10 \% \min . I \text { e } 35 \%<\text { hall }<70 \% \\
& B x \quad-<10 \% \min . \text { I e }<35 \% \text { hall } \\
& \text { Ro }->10 \% \min . I
\end{aligned}
$$

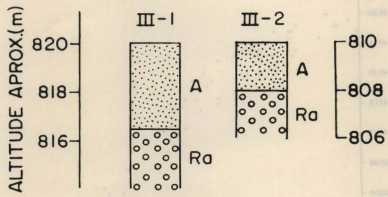

$$
\begin{aligned}
& A-<10 \% \min . \mathrm{I} \text { e }>70 \% \text { hall } \\
& \text { Ro }->10 \% \min . \mathrm{I}
\end{aligned}
$$




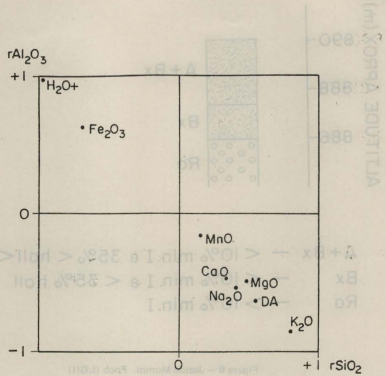

Figura 8 - Diagrama $\mathrm{rSiO}_{1} \times \mathrm{rAl}_{2} \mathrm{O}$, para os principais oxidos

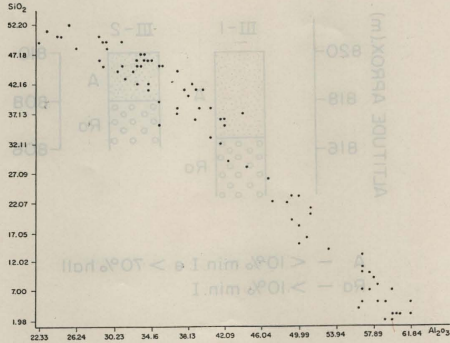

Figura 9 - Diagrama de correlação entre $\mathrm{Al}_{2} \mathrm{O}$, e $\mathrm{SiO}_{2}$ 


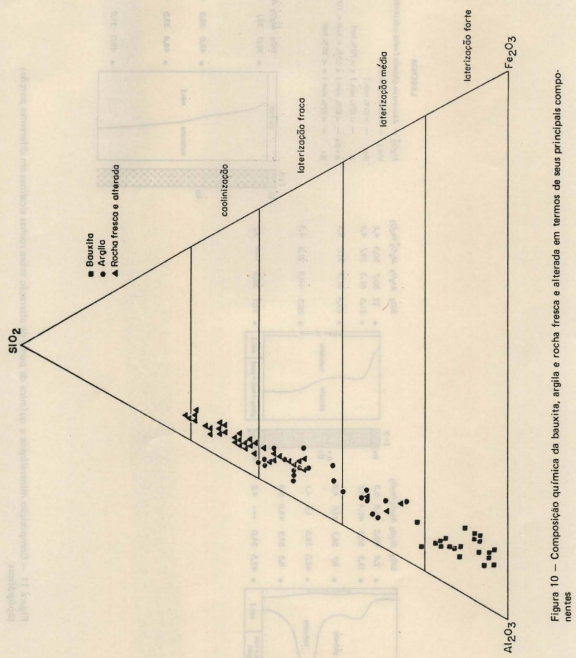



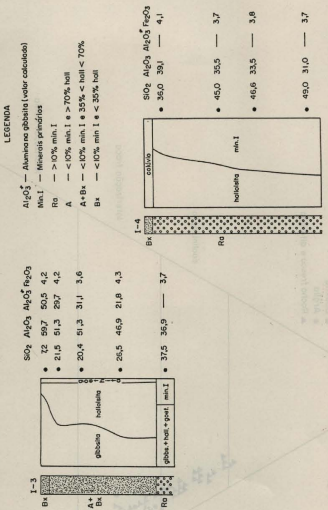

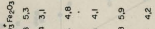

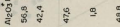

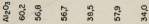

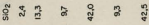

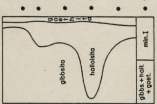

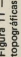

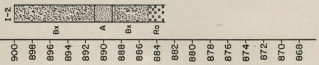

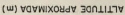




$$
\frac{K L K}{L E L}
$$



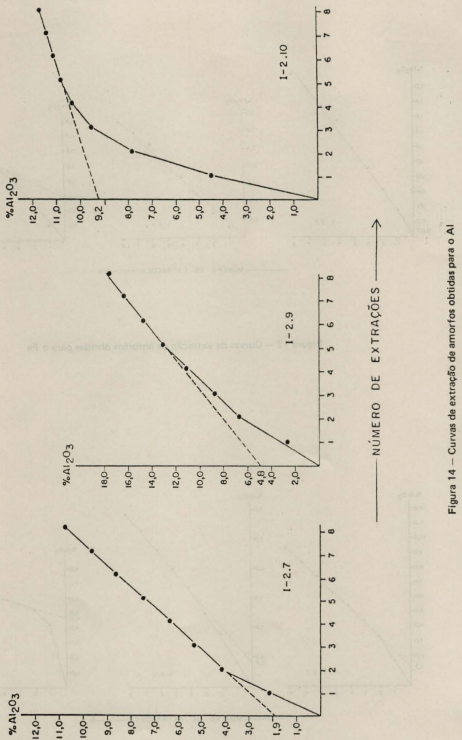


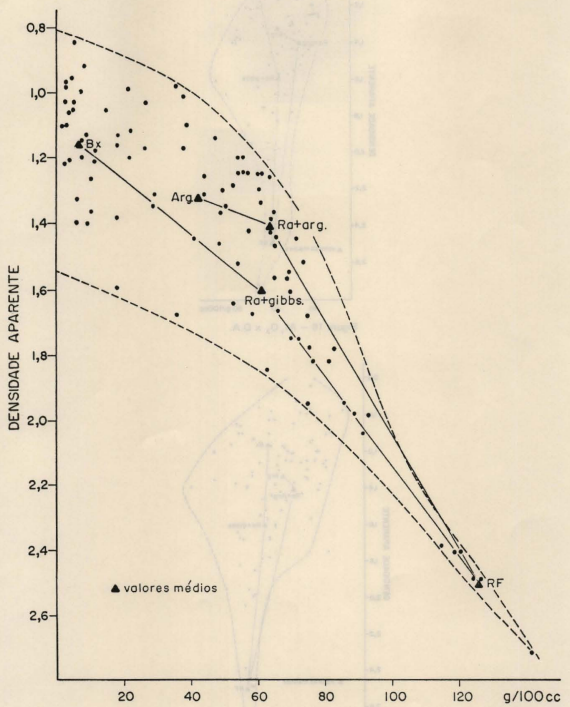

Figura $15-\mathrm{SiO}_{2} \times$ D.A. 


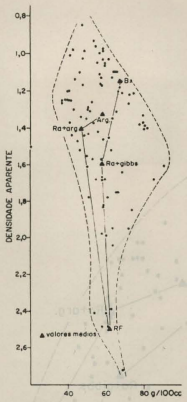

Figura $16-\mathrm{Al}, \mathrm{O}, \times \mathrm{D} . \mathrm{A}$.

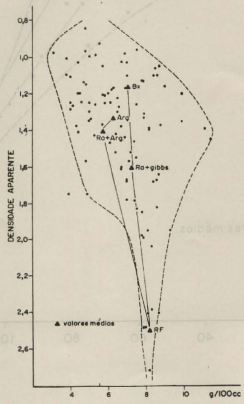

Figura $17-\mathrm{Fe}_{2} \mathrm{O}, \times$ D.A. 


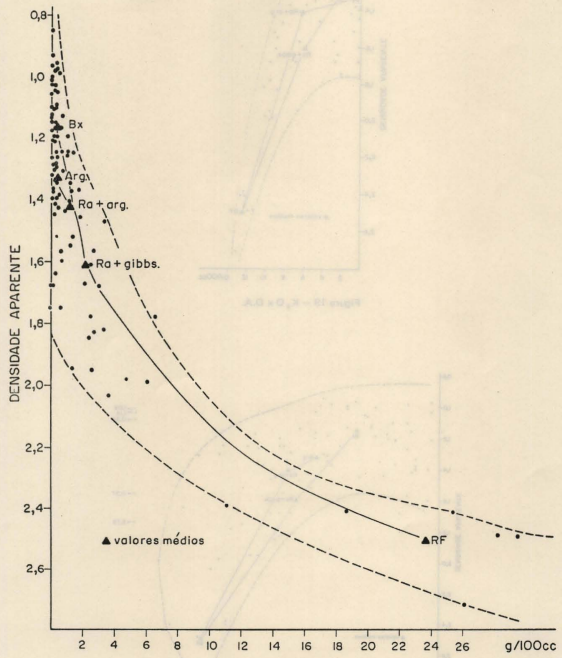

Figura $18-\mathrm{Na}_{2} \mathrm{O} \times$ D.A. 


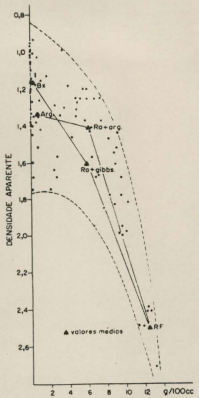

Figura $19-\mathrm{K}_{2} \mathrm{O} \times$ D.A.

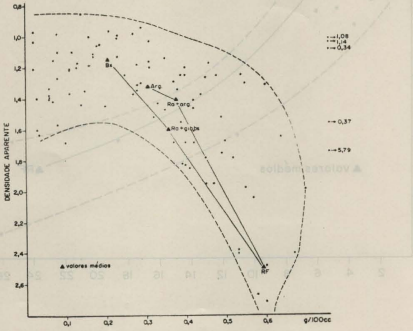

Figura $2 \mathrm{O}-\mathrm{MnO}_{2} \times$ D.A. 

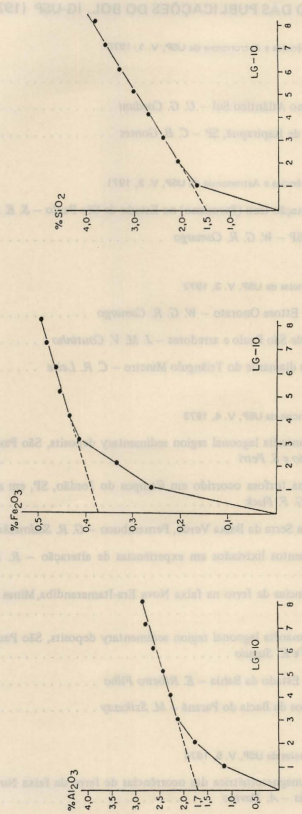